\title{
Article \\ Influence of Water-Induced Degradation of Polytetrafluoroethylene (PTFE)-Coated Woven Fabrics Mechanical Properties
}

\author{
Andrzej Ambroziak *(D) and Paweł Kłosowski \\ Faculty of Civil and Environmental Engineering, Gdansk University of Technology, 11/12 Gabriela Narutowicza \\ Street, 80-233 Gdansk, Poland; klosow@pg.edu.pl \\ * Correspondence: ambrozan@pg.edu.pl; Tel.: +48-58-347-2447
}

check for

updates

Citation: Ambroziak, A.; Kłosowski,

P. Influence of Water-Induced

Degradation of

Polytetrafluoroethylene

(PTFE)-Coated Woven Fabrics

Mechanical Properties. Materials 2022,

15, 1. https://doi.org/10.3390/

ma15010001

Academic Editor: Luigi Coppola

Received: 19 November 2021

Accepted: 16 December 2021

Published: 21 December 2021

Publisher's Note: MDPI stays neutral with regard to jurisdictional claims in published maps and institutional affiliations.

Copyright: (c) 2021 by the authors. Licensee MDPI, Basel, Switzerland. This article is an open access article distributed under the terms and conditions of the Creative Commons Attribution (CC BY) license (https:// creativecommons.org/licenses/by/ $4.0 /)$.
Abstract: The impact of water-induced degradation on the mechanical properties of the chosen two PTFE-coated, glass threads woven fabrics is investigated in this paper. The paper begins with a survey of literature concerning the investigation and determination of coated woven fabric properties. The authors carried out the uniaxial tensile tests with an application of flat and curved grips to establish the proper values of the ultimate tensile strength and the longitudinal stiffness of groups of specimens treated with different moisture conditions. Despite the water resistance of the main materials used for fabrics manufacturing, the change of the mechanical properties caused by the influence of water immersion has been noticed. The reduction in the tensile strength resulting under waterlogged is observed in the range from $5 \%$ to $16 \%$ depending on the type of investigated coated woven fabric and direction of weft or warp.

Keywords: construction materials; water-induced degradation; PTFE coated woven fabric; uniaxial tensile test; mechanical properties

\section{Introduction}

The glass threads, polytetrafluoroethylene (PTFE)-coated woven fabrics are one of the most popular types of architectural fabrics applied in membrane structures (see Figure 1) and are increasingly used for facades. The impressive and unordinary membrane structures are designed and built all over the world in different environmental conditions (see e.g., Shopping mall Titan Plaza, Bogotá, Columbia [1], London 2012 Olympic Stadium [2], Winter Garden, Verona, Italy [3]).

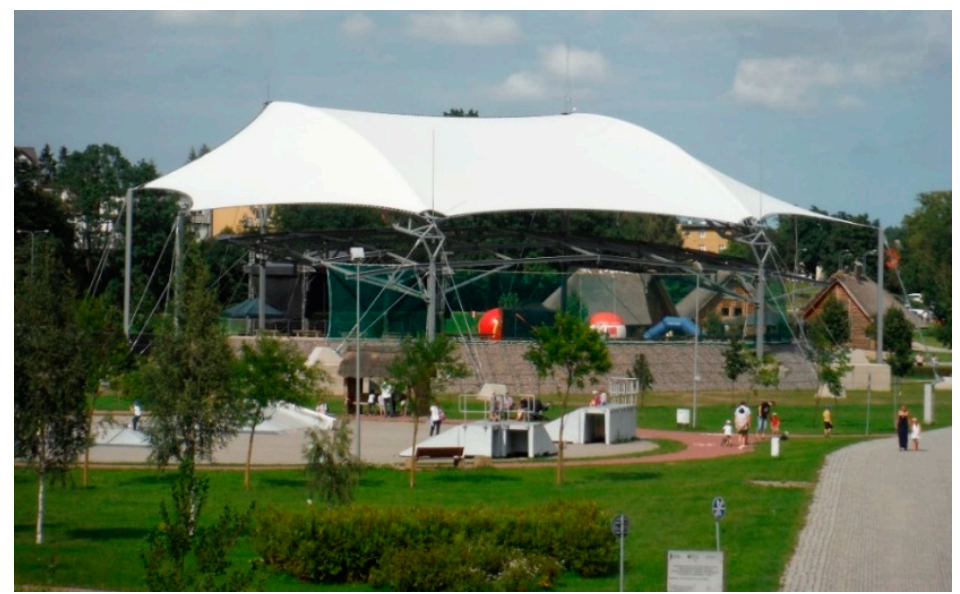

Figure 1. Membrane hanging roof co-designed by the authors in Pruszcz Gdanski, Poland.

The coated woven fabrics called architectural fabrics spark a vital interest in the community of engineers, designers, and scientists to take into consideration, as the subject 
of different investigations to describe their complex mechanical behavior and influence on thermal and environmental conditions. In the beginning, the authors decided to perform a survey of literature concerning the investigation carried out on coated woven fabrics with topical grouping to show how the widespread research and development area of coated woven fabrics is.

Due to discrete microstructure, non-linear, and inelastic strain-stress relationships of the coated woven fabrics, a large number of the constitutive models are proposed and developed [4]. Hass [5] and Pierce [6] in early works investigated force models of woven fabric in membrane structures. Argyris et al. [7] presented rheological relations and numerical simulations for PVC-coated fabrics. Szostkiewicz-Chatain and Hamelin [8] developed stiffness and inverse identification methods for polyester fabrics. Bridgens and Gosling [9] developed the direct stress-strain material model for coated woven fabrics. Pargana et al. [10] introduced a new constitutive model to deal with coated fabrics. Galliot and Luchsinger [11] performed a shear ramp test for technical fabrics and proposed a nonlinear material model. Derewonko et al. [12] proposed a basic material model for numerical simulation based on the uniaxial tensile test for coated fabric material. Ambroziak and Kłosowski [4] proposed the layered dense net model to describe the behavior of coated woven fabrics. Meng and Wu [13] applied a generalized Maxwell model to describe the viscoelastic properties of coated fabrics under relaxation tensile tests. Jekel et al. [14] proposed an inverse bubble inflation test utilizing full displacement field matching to obtain the nonlinear material model. Hegyi et al. [15] proposed a new, two-dimensional phenomenological model for the description of technical woven fabrics. Jekel et al. [16] developed a non-linear orthotropic material model to capture the behavior of PVC-coated polyester under tensile tests. Dib et al. [17] described the non-Newtonian viscous behavior of a coated woven fabric through a proposed material model. Motevalli et al. [18] proposed three hyperelastic orthotropic material models for the simulation of a glass-PTFE membrane. $\mathrm{Xu}$ et al. [19] investigated the shear behavior of PTFE-coated fabrics by picture frame tests and proposed the phenomenological model of PTFE-coated fabrics. Zhao et al. [20] proposed a nonlinear constitutive model for the description of the coted woven fabrics under uniaxial tensile loading.

The different types of laboratory tests (e.g., uniaxial and biaxial tensile tests) are performed to a proper description of the behavior of the coated woven fabrics. Reinhardt [21] compared uniaxial and biaxial tensile test results for chosen PVC-coated polyester fabrics. Day [22] performed biaxial tensile tests for coated fabrics at variable stress ratios. Chen et al. [23] carried out biaxial and uniaxial tensile tests for polyester, PVC-coated woven fabrics. Zouari et al. [24] described the behavior of architectural fabrics under biased tensile tests. El-Messiry and Youssef [25] investigated the relation of the strain-stress contours distribution in a tensioned fabric under a central force. Derewońko et al. [26] investigated the effect of the width of a specimen cut out from coated fabric subjected to uniaxial tensile on the transverse deformation of the material. Ambroziak and Kłosowski [27] performed biaxial and uniaxial tests for AF9032 architectural fabric. Chen et al. [28] experimented on a Uretek321A envelope fabric under biaxial and uniaxial tensile tests. Chen et al. [29] determined for Uretek3216 fabric the Poisson's ratio change under biaxial tests. BögnerBalz et al. [30] described materials used in textile architecture and showed the mechanical behavior of coated fabrics. Ambroziak [31] investigated mechanical properties of Precontraint 1202 polyester coated fabrics under biaxial tensile tests with different load ratios. Ambroziak [32] performed the biaxial and uniaxial experimental tests for FR 8540 polyester type fabric. Chen and Chen [33] predicted the uniaxial tearing strength for Uretek3216LV coated fabrics. Wu et al. [34] focused on the uniaxial and biaxial mechanical properties for ethylene tetrafluoroethylene foil and suggested optimal partial safety factors for this material. Shi et al. [35] proposed the novel test method of the biaxial bias-extension method and studied the shear behavior of chosen architectural coated fabrics. Chen et al. [36] carried out tensile tests for coated biaxial warp-knitted fabric with different bias angles to estimate the Poisson's ratios. Shi et al. [37] focused on the biaxial properties of PTFE 
coated architectural fabric membrane with a new specimen and digital image correlation method. Chen et al. [38] examined the warp-knitted fabric PVDF subjected to biaxial loads and described mechanical behaviors under multiple stress ratios. Gao et al. [39] proposed a stress-ratio dependence coefficient to represent the proportion of elongation and shrinkage in different stress ratios on a biaxial monotonic tensile test of PVDF-coated fabrics.

Besides uniaxial and biaxial tensile tests a cyclic, creep, tearing, etc. tests are carried out to show and measure additional complex behaviors of coated woven fabrics. Ansell et al. [40] investigated PTFE-coated woven fabrics exposed to cyclic environmental and creep stresses aging in artificial and natural environments. Ambroziak and Kłosowski [41] studied the mechanical properties of polyvinyl chloride-coated fabric under cyclic tests. Zhang et al. [42] focused on the tensile properties of coated fabrics under monotonous forces and cyclic loads. Wang et al. [43] carried out the cycling-uniaxial tensile tests based on the mono-uniaxial tensile experiments. Junhao et al. [44] investigated off-axial tensile behaviors of polytetrafluoroethylene-coated woven glass fibers under different loading rates. Żerdzicki et al. [45] presented the mechanical response of the VALMEX fabric during the cyclic loading-unloading and reloading experiments. Zhao et al. [46] proposed a method for long-term uniaxial creep tests of membrane materials. Uhlemann et al. [47] developed a saturation analysis procedure to assess the mechanical saturation behavior of five biaxial 1000-load cycle saturation of PES-PVC architectural fabrics. Eun et al. [48] investigated the mechanical properties of PVC-coated fabrics with various viscosity PVC resins and studied the mechanical properties of PVC-coated fabrics with various weaving structures such as plain weave structure, matt weave structure. Chen et al. [49] described uniaxial tearing tests, the influence of slit parameters, off-axis angles, and loading speeds on tearing behavior and strength. Elthan [50] investigated structural parameters affecting the tear strength of the cotton woven and duct fabrics and PVC coated fabrics. Chen et al. [51] investigated the fracture failure analysis on plain-woven laminated fabrics used in stratospheric airship structures. Sun et al. [52] described the tearing residual strength models of cracked PVC coated fabric and PTFE coated fabric under uniaxial tensile tests. He et al. [53] investigated biaxial tearing properties of PVC-coated fabrics using digital image correlation. Sun et al. [54] experimental and analytical investigation on central crack tearing properties of PTFE coated fabric. Xu et al. [55] described the puncture resistance behaviors of architectural coated fabric and its influence on the effects of boundary condition, penetrator shape, yarns angle, puncture rate, the weight percentage of fiber, and coating on puncture resistance behaviors of coated fabric. Li et al. [56] described the central tearing behaviors of PVDF coated fabrics with initial notches under the influence of notches number, notches length, and notches orientation.

Generally, the final product used directly in the tensile structures is tested. Nevertheless, some works investigated also uncoated fabric. Chen et al. [57] investigated coated fabrics before and after coating under tensile tests and compared their mechanical properties. Wang and Zhang [58] compared the tensile strength of uncoated and coated technical fabrics. Wang et al. [59] focused on the stab failure behavior of coated and uncoated woven fabric. These scientific works allow evaluating the influence of the coating application on the behavior of coated fabrics.

Investigations on a description of material and mechanical properties for different coated woven fabrics are widely conducted also. Bassett et al. [60] reviewed various experimental approaches for coated fabrics to assess the mechanical parameters. Kłosowski et al. [61] determined the viscoplastic properties of coated fabrics. Kłosowski et al. [62] applied a nonlinear viscoelastic model for the PVC-coated polyester fabric. Żerdzicki et al. [63] applied the elasto-viscoplastic Bodner-Partom model for Valmex coated fabric. Uhlemann et al. [64] described and compared two different methods of determining stiffness parameters for three types of PVC-coated fabrics under biaxial tensile tests. Chen et al. [65] investigated the penetration-resistant capability of PVC-coated polyester fabric using a pneumatic cannon system. Van Craenenbroeck et al. [66] described the material properties of PVC-coated polyester fabric and their validation. Meng et al. [67] 
applied the Monte Carlo simulation algorithm based on the Ising model to analyze the force-displacement curve with different regions under uniaxial tensile tests. Meng et al. [68] applied the simplified maximum stress criterion and a modified Tsai-Hill criterion to predict the failure of the coated fabrics under on-axial and off-axial tension. Zhao et al. [69] described an in situ method to determine the stress distribution of an inflatable membrane structure using a force-finding method based on measured configuration. Dinh et al. [70] proposed a method to combine different stages in the design and analysis of membrane structures at tension within the shape optimization framework. Kłosowski et al. [71] analyzed technical fabrics' behavior thoroughly through viscoplastic Bodner-Partom constitutive law. Chen et al. [72] examined coated URETEK 3216 LV fabrics under mono-uniaxial, biaxial, and uniaxial cyclic loads. Ambroziak and Kłosowski [73] identified mechanical properties for the sail technical woven fabric style 480 AP (yacht sailcloth polyester) with a medium tempered optimized finish. Xu et al. [74] investigated off-axis mechanical behaviors of PVC-coated fabrics by digital image correlation technology to measure the shape, displacement, and strain. Chen et al. [75] developed a MATLAB program for achieving complex deformation properties and accurate elastic parameters of woven fabrics under biaxial tests. Khaothong [76] used the Taguchi method for investigated factors affecting the strength of welding seam through hot air for PVC-acrylic coated polyester fabrics.

A large number of investigations are also performed on assessment changes of coated woven fabric properties influences by temperature, aging processes, or other factors. Zhang et al. [77] determined mechanical properties and applied a temperature reduction factor for coated woven fabrics. Ambroziak and Kłosowski [78] identify mechanical and thermal properties of PVC-coated polyester fabrics in the range of temperature form $-30{ }^{\circ} \mathrm{C}$ to $+70^{\circ} \mathrm{C}$. Jabbari et al. [79] described the thermal degradation, effect of aerogel-content, thermal insulating properties, surface characteristics, and tensile properties of polyester fabrics. Zhang et al. [80] performed research on the stress-relaxation behaviors of PTFE coated fabrics under temperatures from $23{ }^{\circ} \mathrm{C}$ to $70{ }^{\circ} \mathrm{C}$. Meng et al. [81] examined thermal distribution and deformation of coated woven fabrics. Yu et al. [82] studied the mechanical properties of polyvinyl chloride PVC-coated woven fabric exposure to temperature ranges from $20{ }^{\circ} \mathrm{C}$ to $170{ }^{\circ} \mathrm{C}$ under the uniaxial tensile test. Sun et al. [83] investigated the temperature effects (ranging from $23^{\circ} \mathrm{C}$ to $250{ }^{\circ} \mathrm{C}$ ) on the mechanical properties of the polyester-coated fabric membrane materials under uniaxial loading. Li et al. [84] investigated the effects of natural aging on the properties of a polyvinylidene fluoride PVDF-coated fabric. Zhang and Zhang [85] described the degradation behaviors of PVDFcoated polyesters by artificial accelerated tests and studied the effects of environmental factors and loading conditions. Zerdzicki et al. [86] investigated the influence of service aging on polyester-reinforced polyvinyl chloride-coated fabrics under uniaxial tensile, biaxial tensile, and long-term creep tests. João et al. [87] studied the durability of two architectural membranes at the initial stages of environmental exposure, one with polyester fiber coated with polyvinylchloride and the other with glass fiber coated with PTFE. Yang et al. [88] performed statistical characteristics of naturally aged polyvinylidene fluoride PVDF-coated fabrics' mechanical properties and described reliability indexes based on the central point method and Rackwitz-Fiessler method. Klosowski et al. [89] studied thermal aging evaluation for polyester-reinforced and polyvinyl chloride coated fabrics and specified the mechanical properties of the aged fabric using the identified linear piecewise model and by the Bodner-Partom model. Dobilaite et al. [90] performed an experimental study of the tearing behavior of PVC-coated fabrics exposed to different accelerated aging conditions. Shang et al. [91] examined three groups of PVDF-coated fabrics removed from different membrane structures which were used for 15, 16, and 19 years. Toyoda et al. [92] pointed, that a decrease of the tensile strength of PTFE coated glass woven fabric is observed when fabric was immersed into hot water. Razak [93] evaluated the weather ability of PTFE- and PVC-coated fabrics under tropical climate on outdoor exposure tests for 2 years. Asadi et al. [94] investigated water diffusion and water-induced degradation mechanisms 
(on the tensile strength and the breaking strain) of glass/polytetrafluoroethylene (PTFE) architectural fabrics.

The literature concerning coated woven fabrics is very extensive, nevertheless, the authors pay attention to chosen studies concerning the wide and comprehensive studies on the coated woven fabrics. The literature review indicates research concerning constitutive models, different types of laboratory tests, determination of material and mechanical properties, assessment of coated woven fabric mechanical properties changes under different factors, etc. The studies concerning water-induced degradation on coated woven fabrics are limited. Therefore, there is a necessity for carrying out detailed and extended research in this area. Continuous development in textile and membrane materials provides an impulse to conduct new investigations on coated woven fabrics. It can be mentioned that coated fabrics are still developed, tested, and investigated by engineers, researchers, and scientists.

The fabrics producers usually provide the designer with strength parameters for dry material. But when the final construction is exposed to changing weather conditions, especially during the rain or winter season, when rain or wet snow can remain for a long time on the roof surface, the tensile strength can be reduced. There are many factors, which can affect the mechanical properties and final behavior of the coated woven fabrics. Environmental conditions that occur during coated woven fabric exploitation (e.g., build-in membrane or hanging structures) seem to be a prominent factor. One of that factors is rain and high moisture. The present study is aimed at the determination of the influence of water-induced degradation on mechanical parameters of chosen PTFE-coated woven fabrics on changing of mechanical properties under uniaxial tensile tests with an application of two types of grips (flat and curved). This paper provides scientists, engineers, and designers with experimental assessments of the influence of water-induced degradation on mechanical parameters (tensile strength) of investigated two types of PTFE-coated woven fabrics.

\section{Materials and Methods}

Two woven fabrics having glass threads coated by PTFE were chosen for laboratory tests. According to manufacturers' (Saint-Gobain Performance Plastics, Merrimack, United States and Verseidag-Indutex $\mathrm{GmbH}$, Krefeld, Germany) declarations given in Table 1, their basic properties are similar. Both architectural fabrics have similar construction and total weight (difference about $0.7 \%$ ) with about $7 \%$ difference in weight of base threads net per unit area. As declared by manufacturers tensile strength in the warp and weft directions differs about $5 \%$ and $10 \%$ between S-type and B-type. In the year 2006, both PTFE-coated woven fabrics were considered as the potential construction material for the membrane roof of the Forest Opera in Sopot (Poland).

Table 1. Properties of investigated PTFE coated woven fabrics.

\begin{tabular}{ccc}
\hline Properties & S Type & B Type \\
\hline Total Mass per Unit Area $\left(\mathrm{g} / \mathrm{m}^{2}\right)$ & 1540 & 1550 \\
\hline Tensile Strength $(\mathrm{kN} / \mathrm{m}):$ Warp & 170 & 160 \\
Tensile Strength $(\mathrm{kN} / \mathrm{m}):$ Weft & 156 & 140 \\
\hline Base Coat & PTFE & PTFE \\
\hline Weight per Unit Area of Base Fabric $\left(\mathrm{g} / \mathrm{m}^{2}\right)$ & 625 & 670 \\
\hline Yarn Count (yarn/cm): Warp & 7.1 & 8 \\
Yarn Count (yarn/cm): Weft & 7.5 & 7.5 \\
\hline Translucency at $550 \mathrm{~nm}(\%)$ & 9 & $8-11$ \\
\hline
\end{tabular}

The uniaxial tensile tests were conducted on the Zwick 020 mechanical testing machine (Zwick Roell GmbH, Ulm, Germany), under the video extensometer control based on the digital image correlation method with the base of the optical extensometer of about $50 \mathrm{~mm}$. 
The results from the video extensometer were used to identify the fabric stiffness functions. The specimens had $50 \pm 1 \mathrm{~mm}$ width, and the active length equal to $200 \pm 1 \mathrm{~mm}$ for application of flat grips (see Figure 2a), and the total length of $900 \pm 1 \mathrm{~mm}$ for curved grips (see Figure 2b), respectively. The tests have been performed according to guidelines in the ISO 1421:2016 standard [95] for the strip method, with the displacement rate of the upper grip of $100 \mathrm{~mm} / \mathrm{min}$ (see Figure 2a). Each type of test has been repeated at least three times.

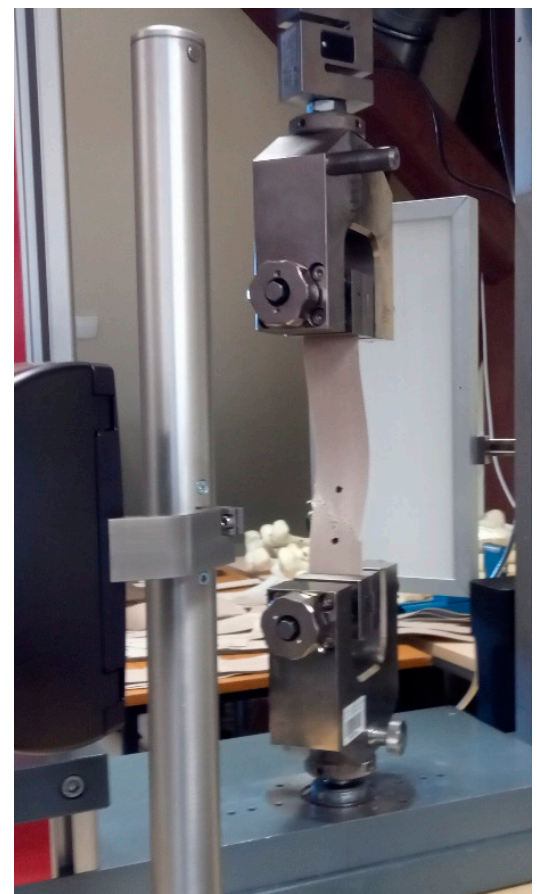

(a)

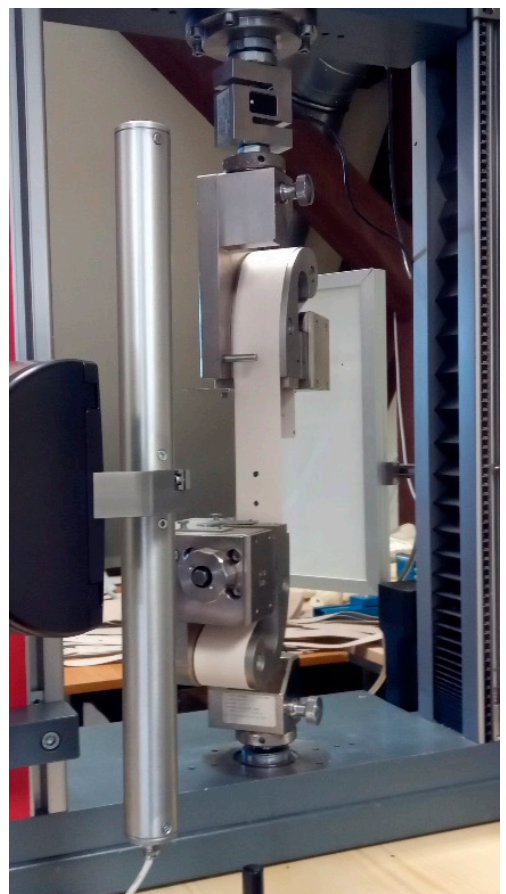

(b)

Figure 2. Uniaxial laboratory tests stand. Coated fabric samples fixed: (a) in flat grips; (b) in curved grips.

Three main groups of coated fabric specimens were tested. All specimens were cut out from the bales of fabric stored for a long time in the laboratory in room conditions. For the first group, the fabric specimens were cut in the warp and weft direction from the base material (virgin fabric). Then they were, measured, weighed, and then immediately tested. Results for this group are denoted S or B regarding $S$ type or B type coated fabrics. The two remaining groups of specimens fabric were immersed into room temperature water for two weeks. The immersion period was twice longer than taken by Asadi et al. [94]. After two weeks they were taken out from the water. Their surface was dried using absorbent paper. The specimens of the second group were weighted and then immediately tested. This group is denoted as S_wet or B_wet reference to coated fabrics S or B types tested as wet. The third group of fabric specimens, after two weeks of water soaking, was left in the room conditions to dry out for the following one week and then weighted and tested. The last group is denoted as S_air-dried and B_air-dried concerning S type or B type coated fabrics subjected to waterlogging and process of air-drying.

To recognize the importance of mechanical parameters changes according to moisture conditions and history of water impact on the coated fabric, the one-way ANOVA statistical analysis (see e.g., [96,97]) was performed. An ANOVA test is a way to find out whether the results of laboratory tests obtained for defined groups of specimens differ significantly from each other. The tests were divided into three groups dry (base specimens), wet, and air-dried, and mechanical properties of each group were investigated. To perform ANOVA tests it is necessary to check whether data have the normal distribution and whether the variances of data sets have the same value. Therefore, before the ANOVA test, the 
assumptions of the normal distribution of results (Shapiro-Wilk test, see e.g., [98]) and the equal variance test (Brown-Forsythe test, see e.g., [99]) were checked. If the data sets would not pass the Shapiro-Wilk test and the Brown-Forsythe test, the ANOVA analysis could not be performed. In all presented results both mentioned tests were passed. The ANOVA test was always performed with the parameter of power performance $\alpha=0.05$.

\section{Laboratory Test Results and Discussion}

\subsection{Measurements of Surface Weight}

After weighing (with an accuracy of $\pm 0.01 \mathrm{~g}$ ) and dimension measuring (with an accuracy of $\pm 1 \mathrm{~mm}$ ) for each sample dry, after soaking, and after air-drying were determined the total mass per unit area for chosen types of PTFE coated woven fabrics. The results of measurements of surface weight determining are collected in Table 2 . The mean value of the mass per unit area as well as the standard error of the mean of the specified range is presented. The measured total mass of the dry coated fabric specimens was about $2 \%$ lower for S-type and 5\% higher for B-type fabric than declared by manufacturers. The determined total mass per unit area for the fabric specimens subjected to 2-weeks soaking process in water was about $1.4 \div 2 \%$ higher than its initial weight. The dried specimens have the total mass per unit area about $0.5 \div 0.8 \%$ lower than the initial what can mean that moisture of the rolled fabric (in that form the fabrics have been stored) was a little bit higher than the dried specimens (higher values were obtained for the B-type fabric). It can be concluded that the lowest total mass per unit area for air-dried fabric specimens than for dry fabric specimens may be connected with the fact that rolled fabric cut into smaller pieces gives off the imprison moisture by cross-section face fastest than by surfaces when are rolled and stored. Additionally, a deviation in the total mass per unit area of the coated fabric itself (e.g., a slight difference in coating thickness) influences the final weight of the coated fabrics.

Table 2. Total mass per unit area $\left(\mathrm{g} / \mathrm{m}^{2}\right)$.

\begin{tabular}{cccc}
\hline & $\begin{array}{c}\text { Dry } \\
\text { (Base Specimens) }\end{array}$ & Wet & Air-Dried \\
\hline S-type & $1511 \pm 4$ & $1532 \pm 4$ & $1503 \pm 5$ \\
B-type & $1638 \pm 4$ & $1670 \pm 4$ & $1625 \pm 4$ \\
\hline
\end{tabular}

The comparison of the surface weight of investigated groups of fabrics showed the statistically important differences for all three groups for the B type of fabric $p<0.05$ and not the important difference between dry and air-dried groups for the $S$ type $(p=0.218)$. That means that the $S$ type of fabric has almost the same density before soaking and after the air-drying process from the statistical point of view.

\subsection{Uniaxial Tensile Tests}

The uniaxial tensile tests were performed to evaluate the tensile strength and the related elongation at break, as well as the fabric stiffness in the specified ranges of deformation. The results (time, displacements measured by extensometer, and the applied force) have been recorded by a computer and recalculated to the stress-strain functions presented in Figure 3 for the $S$ type fabric and in Figure 4 for the B type fabric. Figures $3 \mathrm{a}$ and $4 \mathrm{a}$ are given results for $S$ type and $B$ type fabric with the application of flat grips, respectively. The results for curved grips are shown in Figures $3 b$ and $4 b$. 


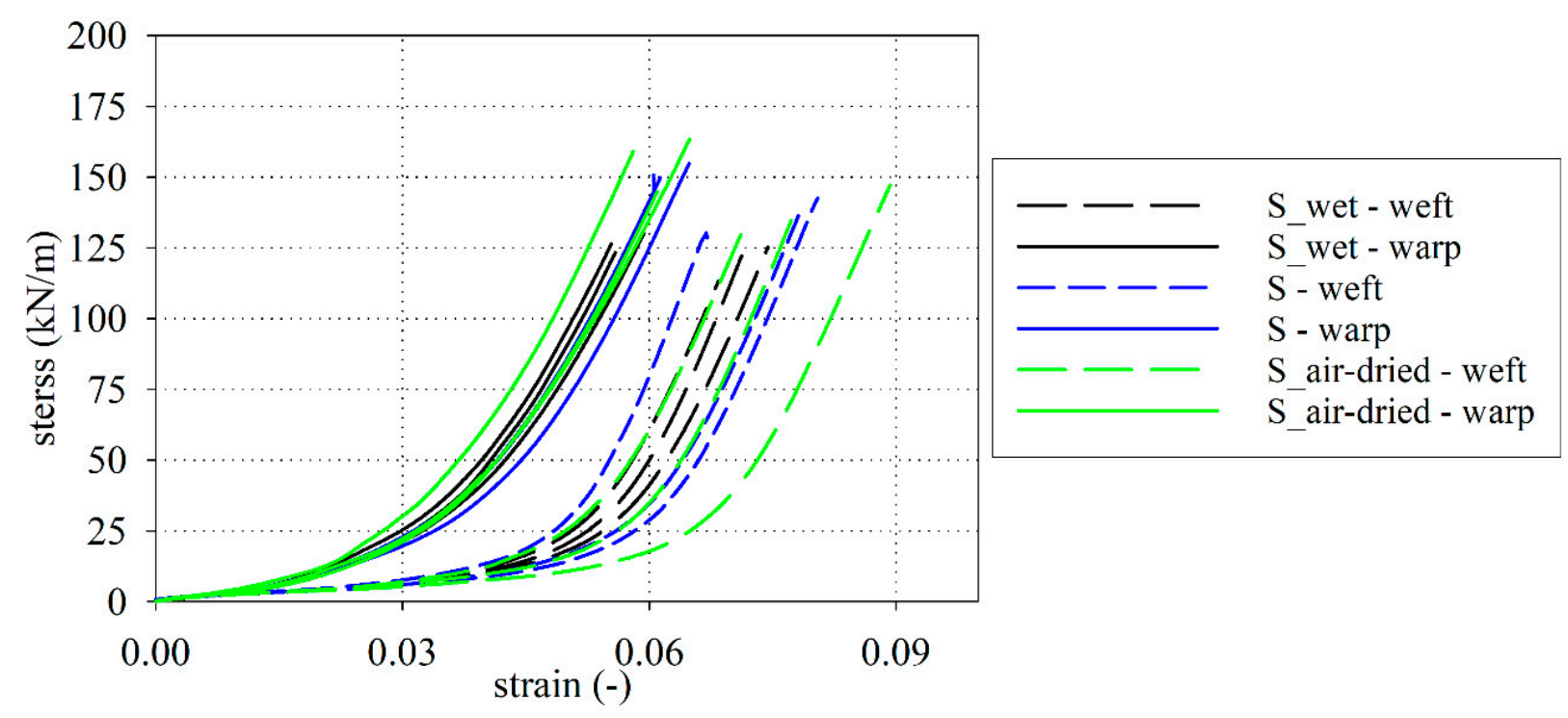

(a)

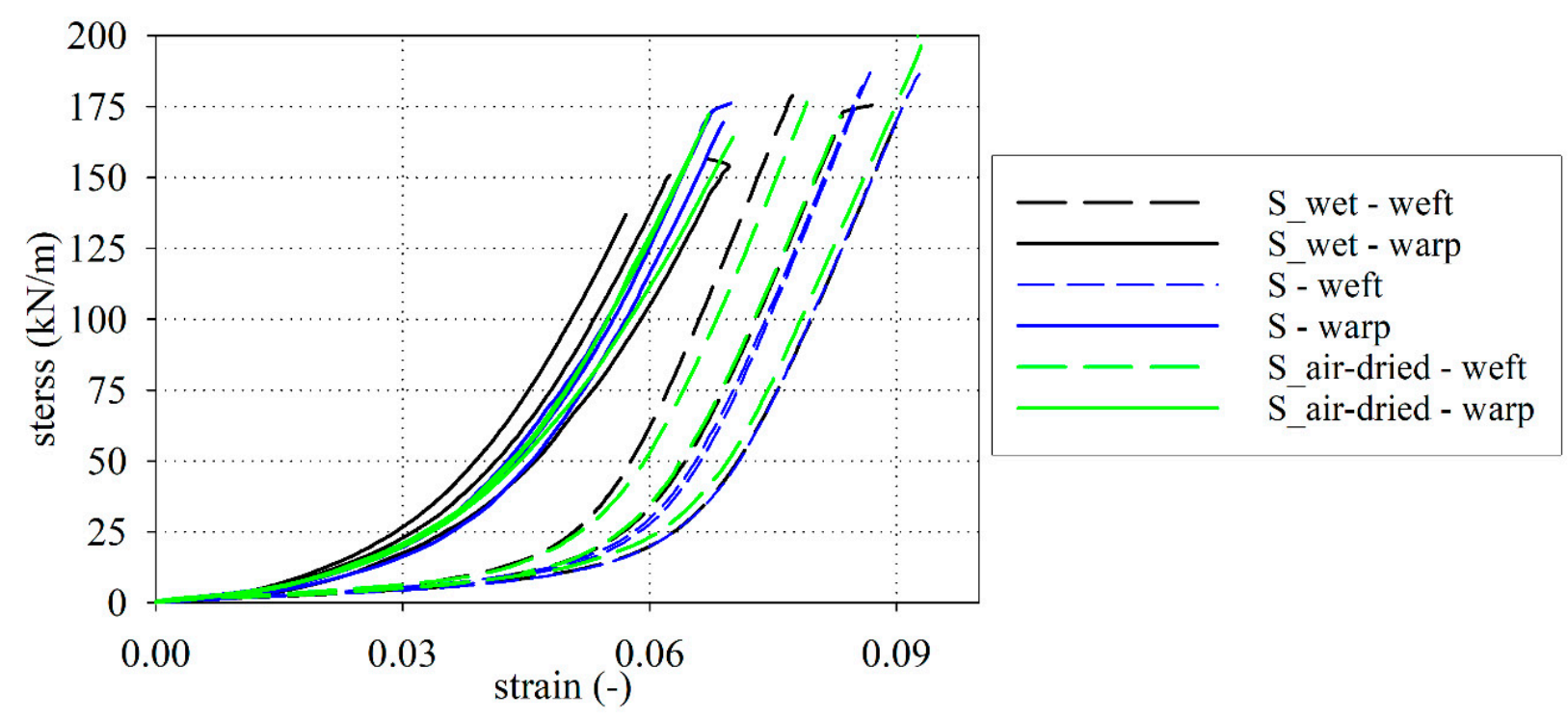

(b)

Figure 3. Stress-strain curves, $\mathrm{S}$ type fabric: (a) flat grips; (b) curved grips. 


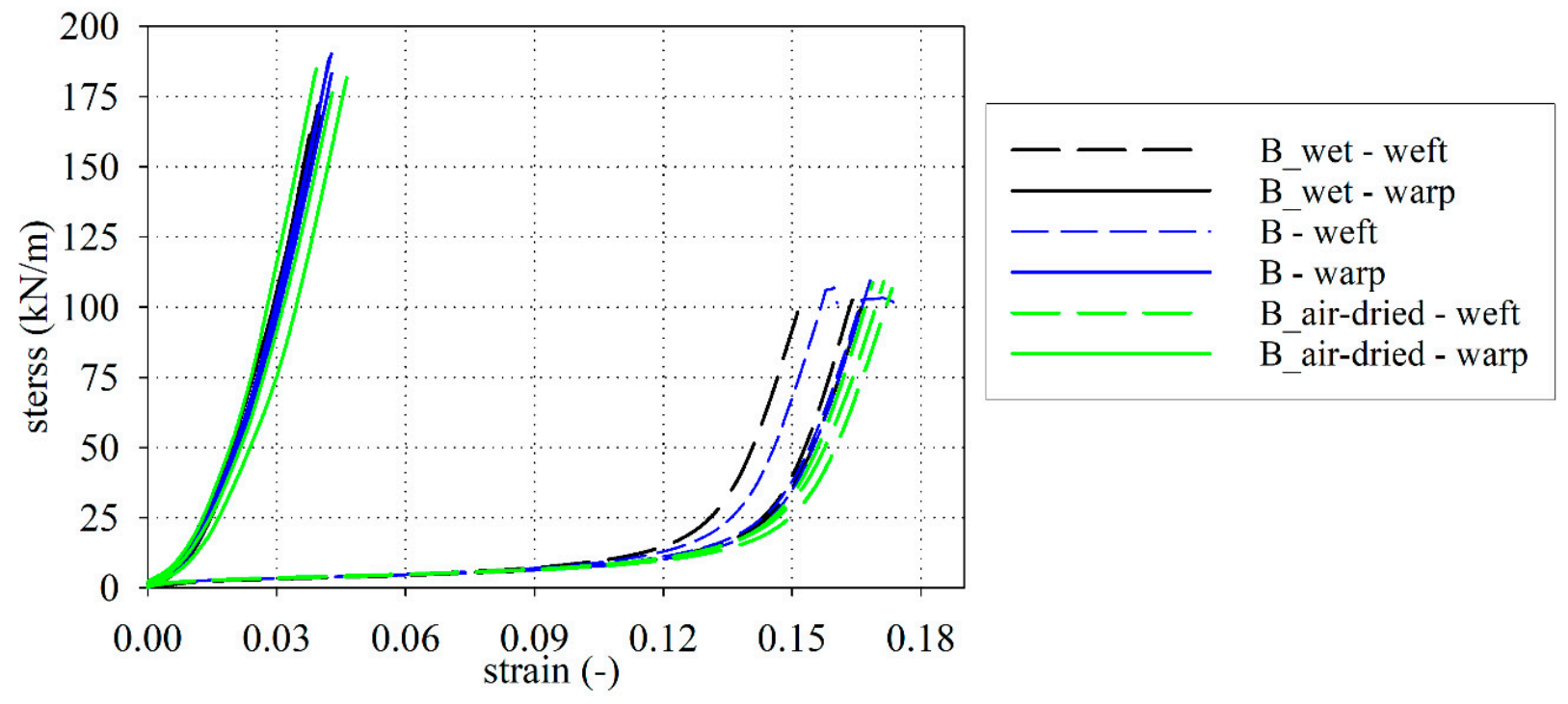

(a)

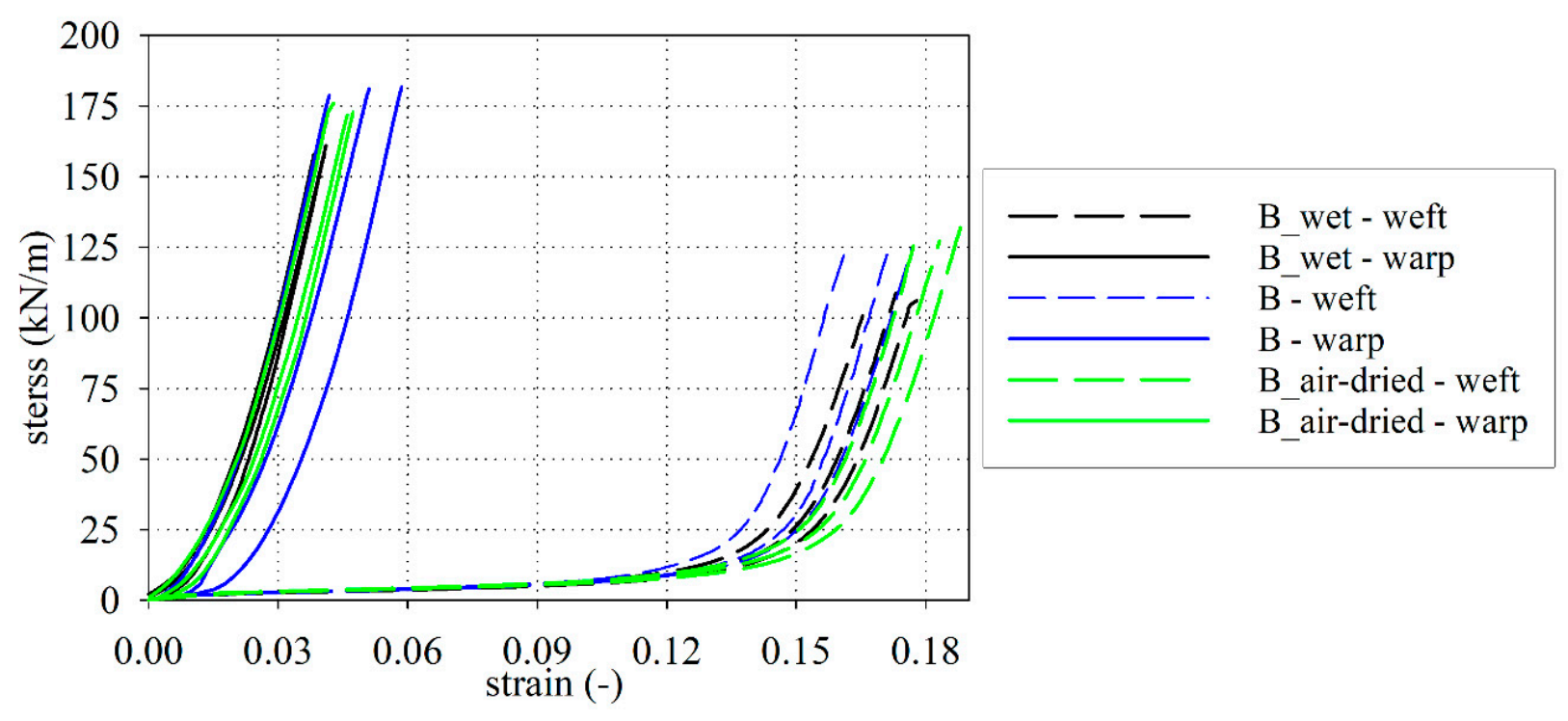

(b)

Figure 4. Stress-strain curves, B type fabric: (a) flat grips; (b) curved grips.

\subsection{Elongation at Break and Tensile Strength}

Based on the performed uniaxial tensile tests the elongation at break and the tensile strength are specified for fabrics investigated under different conditions: dry, wet, and air-dray. For evaluation of the tensile strength, the type of used grips may play an important role. The ISO 1421 standard [95] does not specify what kind of grips should be used. It is required to avoid close to jaw breaks only, see Figure 5 where permitted forms of failure are shown. Nevertheless, the tensile strength obtained using flat grips is usually lower than for curved grips due to close grips stress concentrations of fabric specimens and appearing breaks of fabric specimens close to flat grips during tests. Therefore to compare the moisture influence both sets of results are separated. The uniaxial tensile test results for three groups of fabric specimens (base: S and B, wet: S_wet and B_wet, and air-dried: S_air-dried and B_air-dried) are presented in Appendix A Tables A1-A3 for S type fabric and in Tables A4-A6 for B type fabric. 


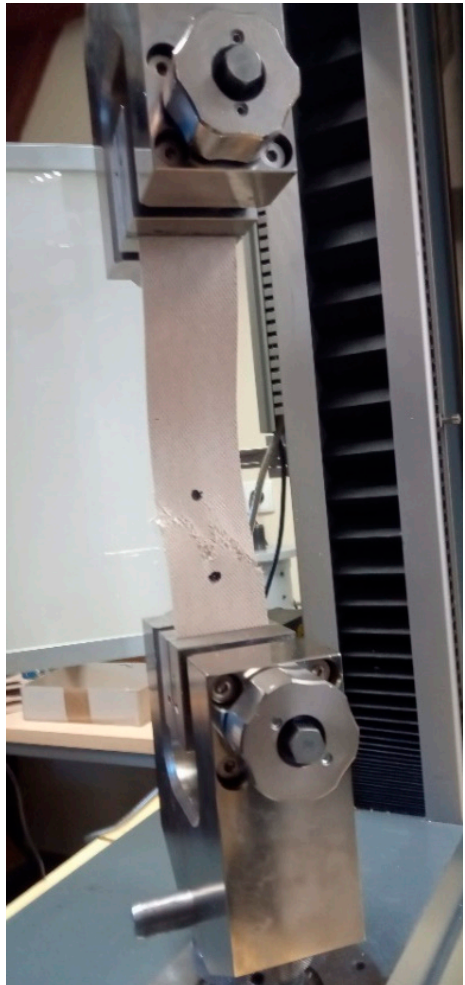

(a)

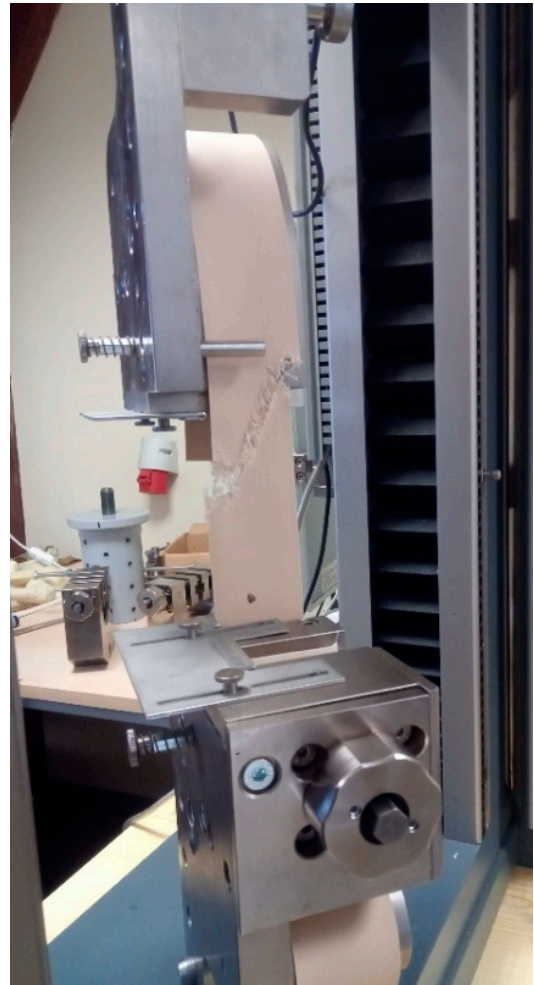

(b)

Figure 5. The typical form of specimens failure under uniaxial tensile tests: (a) flat grips; (b) curved grips.

The large differences between tensile strength (see e.g., in weft direction between flat and curved grips for S, S_wet, S_air-dried, B, B_air-dried) are connected with exhibited of breaks of fabrics specimens near the grips thus the flat grips results sometimes cannot be treated as proper value of the tensile strength of coated fabrics. Nevertheless, in this investigation, for the flat grips results for the B-type fabric in the warp direction, the tensile strength is greater than for curved grips.

The specified mean values of tensile strength of the dry S-type fabric (base specimens) for weft and warp directions is $185 \pm 2 \mathrm{kN} / \mathrm{m}$ and $173.1 \pm 2 \mathrm{kN} / \mathrm{m}$ (see Table A1) and they are higher by $20 \%$ and $2 \%$ than the values declared in Table 1 . For the dry B-type fabric (base specimens) the determining tensile strength is $11 \%$ lower for the weft direction and $20 \%$ higher for warp direction (see Table A4) than declared by the manufacturer, see Table 1. The mean values of the tensile strength for the wet fabrics (S_wet and B_wet) are reduced, see Figure $6 a, b$. In the case of the $S$ type fabric is reduced by $5 \%$ (to $176.4 \pm 2 \mathrm{kN} / \mathrm{m}$ ) in the weft direction, and $20 \%$ (to $148.6 \pm 6 \mathrm{kN} / \mathrm{m}$ ) for the warp direction, see Table A2. The same effect has been obtained for the B-type fabric-reduction by $16 \%$ (to $105.5 \pm 3 \mathrm{kN} / \mathrm{m}$ ) in the weft direction and reduction by $11 \%$ (to $171.8 \pm 2 \mathrm{kN} / \mathrm{m}$ ) for the warp direction, see Table A5. The air-dried fabric specimens obtained a higher mean value of tensile strength than wet fabric specimens, see Figure 6a,b. The difference in mean tensile strength for air-dried fabrics is about $4 \%$ compared to base fabric specimens, see Tables A3 and A6. 


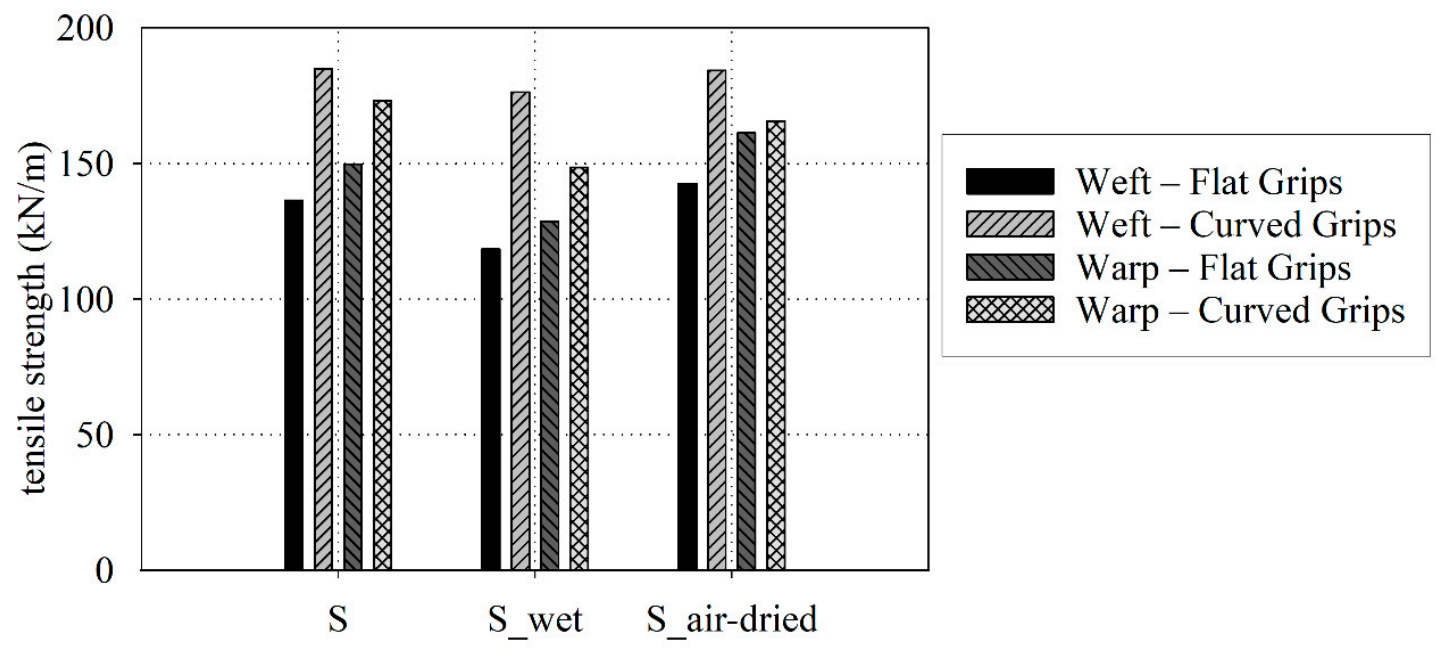

(a)

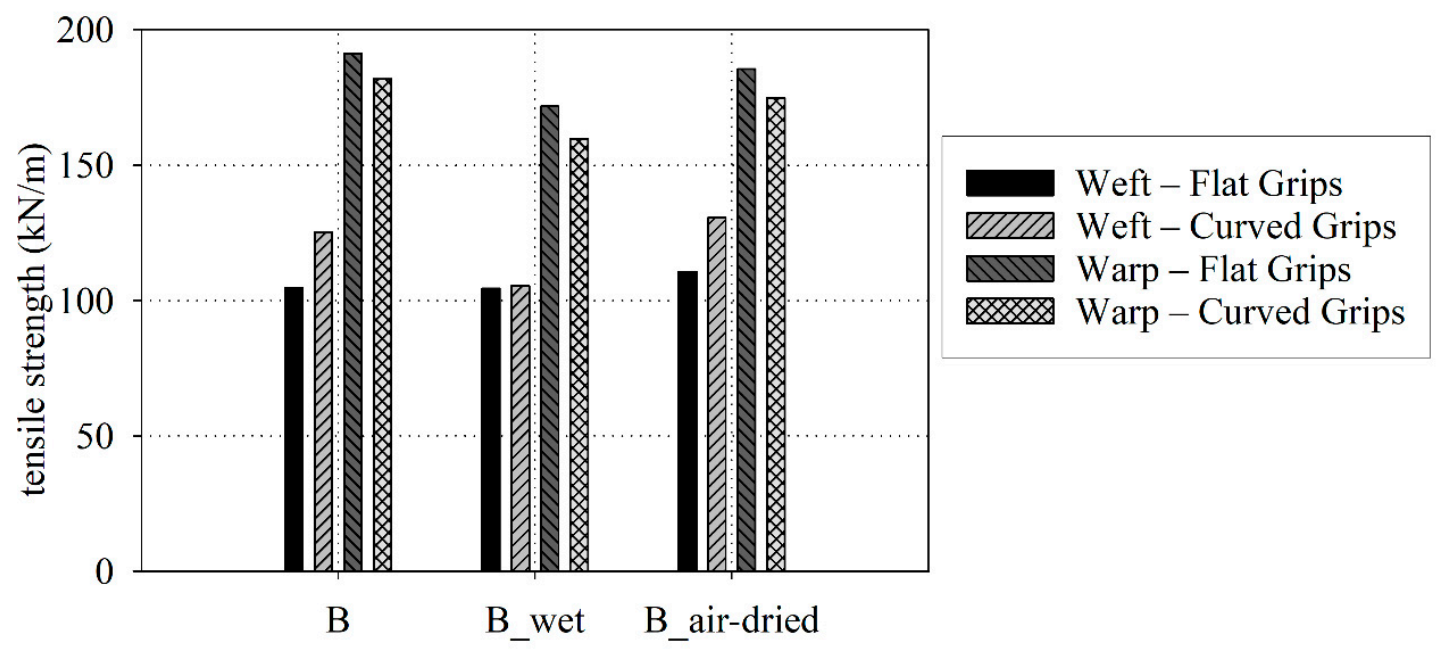

(b)

Figure 6. Tensile strength: (a) S type fabric; (b) B type fabric.

The importance of the influence of water-induced degradation mechanisms on the tensile strength has been verified by the ANOVA one-way statistical analysis. The change of the tensile strength should be analyzed for curved grips as an application of flat grips usually generates the jaws breaks and cause a reduction of the tensile strength, (see Figure 5). For the S-type of fabric more important influence of moisture can be observed in the weft direction, where the important differences have been noticed between dry/air-dried and wet/dry groups $p<0.05$ (for dry/wet $p=0.377$ ). For warp direction the important difference has been obtained for dry/wet comparison only (air-dried/wet $p=0.054$, dry/air dried $p=0.248$ ). For the B-type of fabric, the relevant differences have been obtained for all compared groups.

\subsection{Determination of the Longitudinal Stiffnesses}

Analyzing the stress-strain curves for the $S$ and B types of PTFE-coated fabrics (see Figures 3 and 4), the characteristic points of the curvature change can be observed. To describe the stress-strain curves, it is possible to use the piecewise linear model (see e.g., [41]). In this concept, it is necessary to specify the longitudinal stiffnesses $F_{i}(\mathrm{kN} / \mathrm{m})$ and the intersection points $\varepsilon_{P i}(-)$ which define the range of applicability of the certain longitudinal 
modulus, see Figure 7 . The stiffness coefficients $F_{i}(\mathrm{kN} / \mathrm{m})$ were determined from the linear approximation of the stress-strain relationship using the piecewise linear model.

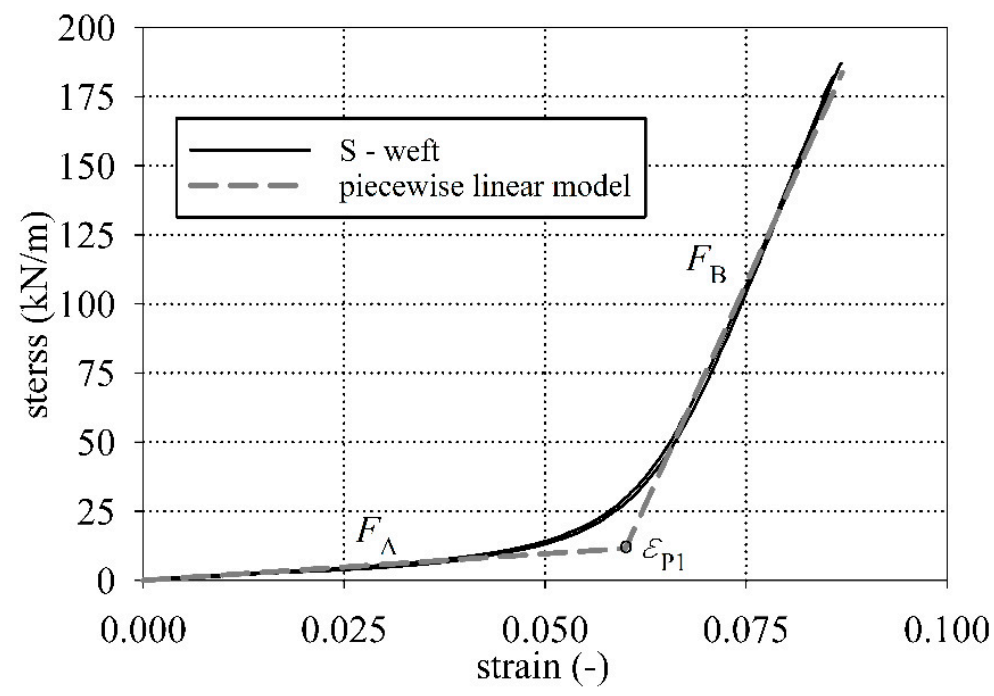

Figure 7. Graphical concept of the piecewise linear model identification.

The application of the video extensometer made it possible to unify the results of tests for flat and curved grips into one group. The video extensometer measures strain in the middle part of the specimen without a touch of the specimen, far from the grips, see Figure $2 \mathrm{~b}$. Therefore obtained strain values used for stiffness identification are determined more precisely. Therefore, the comparison of the waterlogged influence of the fabric stiffness is assumed as not kind of grips dependent. The longitudinal stiffnesses were determined and presented in Figure 8a,b for $\mathrm{S}$ type and B type fabrics, respectively. The tabular results are collected in Table A7 for S-type fabric and in Table A8 for B-type fabric, respectively.

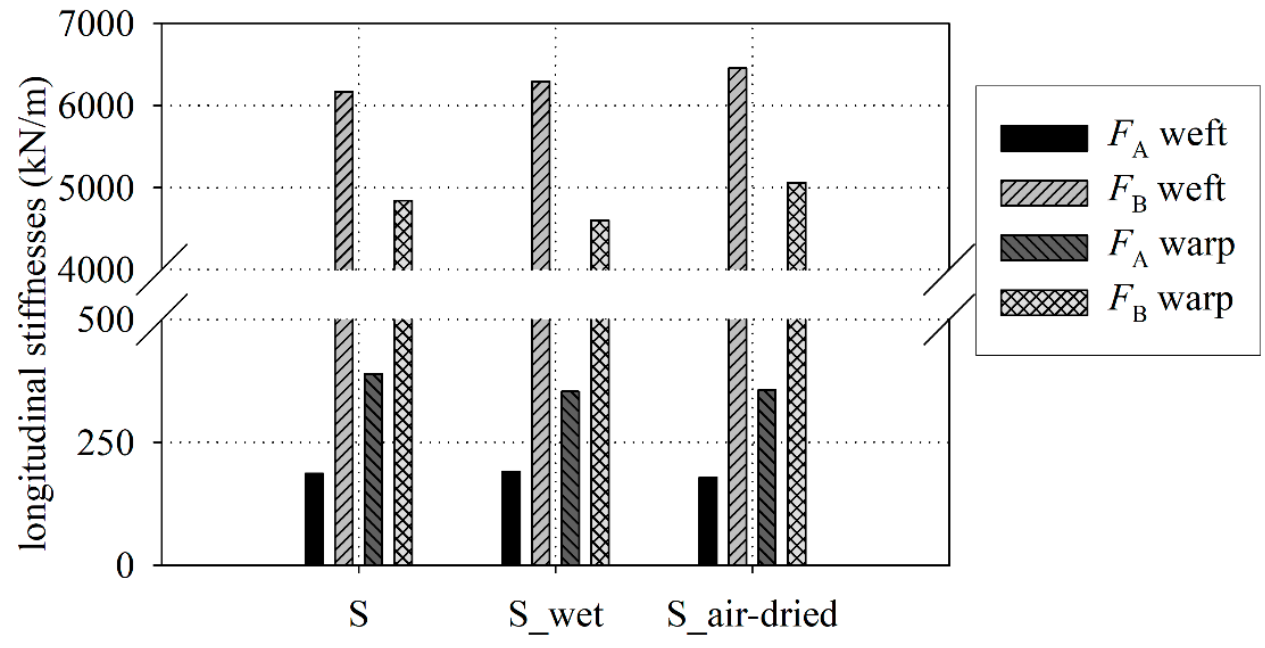

(a)

Figure 8. Cont. 


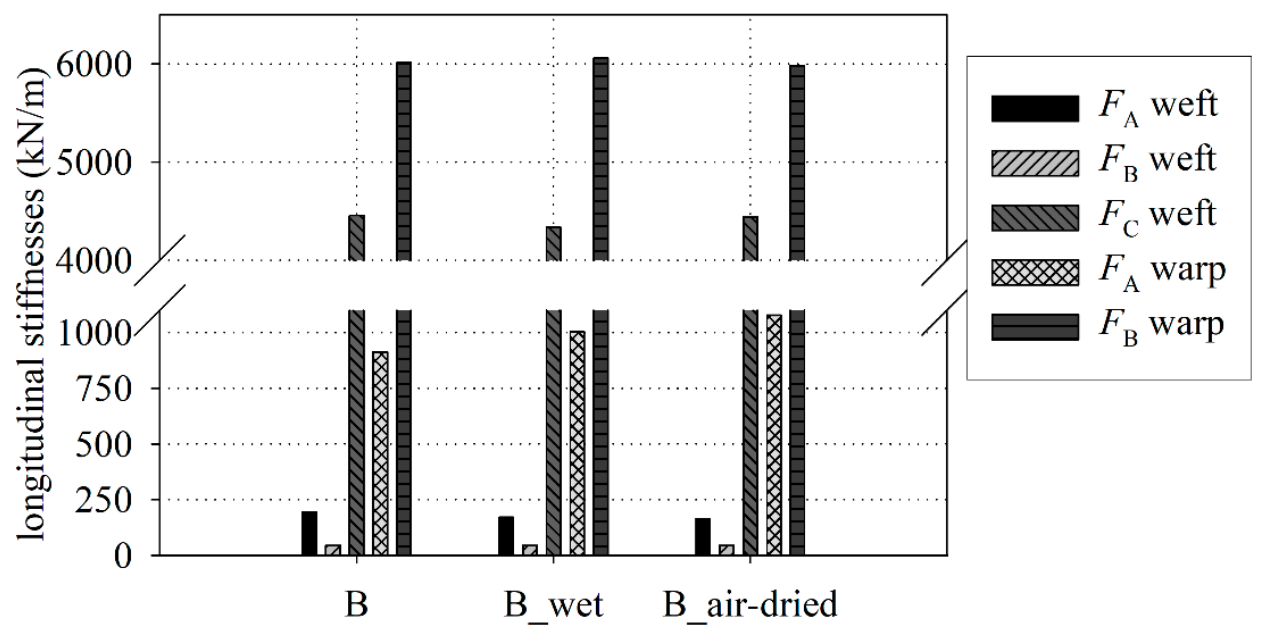

(b)

Figure 8. Longitudinal stiffnesses: (a) S type fabric; (b) B type fabric.

Taking into account the mean stiffnesses of $F_{\mathrm{B}}$ and $F_{\mathrm{C}}$ it may be concluded that the difference of stiffnesses between the dry and wet fabrics ranges from $2 \%$ (for weft) to $5 \%$ (for warp) for the S-type fabric, see Table A7. The difference for the B-type fabric ranges maximally from $0.8 \%$ (for warp) to $3 \%$ (for weft), see Table A8. The mean stiffness $F_{\mathrm{A}}$ of the wet S-type fabric is vary by about $2 \%$ for weft and $9 \%$ for warp in comparison with dry properties, while for the wet B-type fabric differs by about $10 \%$ (for weft and warp), see Figure 8 . The influence of water on the investigated PTFE-coated fabric stiffness is less essential than for the tensile strength. According to performed ANOVA analysis, it can be stated that the differences in the mean values among the investigated groups (dry, wet, and air-dry) are not great enough to exclude the possibility that the difference is due to random sampling variability; there is not a statistically significant difference.

\section{Conclusions}

In the present paper, two chosen architectural fabrics constructed from glass threads and have the PTFE coating (with some additional thin layers) are investigated. The main materials used to produce the fabrics are water-resistant. Nevertheless, the final product is sensitive to the level of moisture. Based on performed investigation the following conclusions may be drawn:

- The reduction in the tensile strength resulting under waterlogged was observed in the range from $5 \%$ (for weft) to $14 \%$ (for warp) for S-type fabric and from $16 \%$ (for weft) to $10 \%$ (for warp) for B-type fabric, respectively. A similar conclusion came from the authors of [94], where the change in the tensile strength under influence of water was specified nearby $20 \%$.

- The mechanical properties of investigated PTFE coated fabric under water-induced are degraded not only via in-plane watering at unsealed cut edges but also via out-of-plane watering through the coating.

- The influence of moisture is not the same for different physical parameters. The most sensitive is the tensile strength.

- Even small moisture changes as it has been reported between the base fabric and air-dried material cause statistically important changes in the tensile strength. The changes in fabric stiffness are much less sensitive and from the statistical point of view, they can be neglected.

- Changes in the stress-strain curve characteristic under different moisture conditions of PTFE coated fabrics cannot be indicated due to the significant scatter of obtained results, see Figures 3 and 4 . 
- The ANOVA analysis indicated that the longitudinal stiffnesses differences among the investigated groups (dry, wet, and air-dry) are not statistically significant. Future investigations should take into account a more large number of specimens to confirm differences.

- Types of grips used in tensile tests influenced the determined values of the tensile strength. The type of grips is not important during the stiffness of fabric determination. Determination of the tensile strength should be rather performed by using the curved grips to avoid the close-to-grip breaks in coated fabric specimens that are often observed when the flat grips are used. Such close-to-grip breaks reduce the tensile strength value.

The paper provides scientists, civil engineers, and designers with knowledge of waterinduced degradation of chosen PTFE-coated woven fabrics' mechanical properties and requirements to applying curved grips during the process of determination of tensile strengths. Determination of the proper values of tensile strengths of coated woven fabrics under environmental conditions requires assessment of the dry and wet conditions. The coated woven fabrics producers should provide the designer with strength parameters for dry and wet material. The obtained results encourage the authors to continue the research directed towards understanding mechanisms of water-induced degradation of coated woven fabrics' mechanical properties, based on an extension of uniaxial tensile tests and biaxial tensile tests for waterlogged fabrics.

Author Contributions: Conceptualization, A.A.; methodology, A.A. and P.K.; validation, A.A. and P.K.; formal analysis, A.A. and P.K.; investigation, A.A. and P.K.; resources, A.A. and P.K.; data curation, A.A. and P.K.; writing-original draft preparation, A.A. and P.K.; writing-review and editing, A.A. and P.K.; visualization, A.A.; supervision, A.A.; project administration, A.A. All authors have read and agreed to the published version of the manuscript.

Funding: This research received no external funding.

Institutional Review Board Statement: Not applicable.

Informed Consent Statement: Not applicable.

Data Availability Statement: All laboratory test results are presented in Figures 3 and 4 . On the request, the numerical version of the results will be provided.

Conflicts of Interest: The authors declare no conflict of interest.

\section{Appendix A}

Results of elongation at break and tensile strength for the base, wet, and air-dried specimens of the A-type and B-type coated fabrics are presented in Tables A1-A6. The determined longitudinal stiffnesses of $S$ type and $B$ type fabrics are collected in Tables A7 and A8, respectively.

Table A1. Elongation at break and tensile strength-base specimens S-type fabric.

\begin{tabular}{|c|c|c|c|c|c|c|c|c|}
\hline \multirow{3}{*}{$\begin{array}{c}\text { Specimens } \\
\text { No. }\end{array}$} & \multicolumn{2}{|c|}{$\begin{array}{c}\text { Weft-Flat Grips } \\
\text { SWp }\end{array}$} & \multicolumn{2}{|c|}{$\begin{array}{c}\text { Weft-Curved Grips } \\
\text { SW }\end{array}$} & \multicolumn{2}{|c|}{$\begin{array}{c}\text { Warp-Flat Grips } \\
\text { SOp }\end{array}$} & \multicolumn{2}{|c|}{$\begin{array}{c}\text { Warp-Curved Grips } \\
\text { SO }\end{array}$} \\
\hline & Rupture Strain & $\begin{array}{l}\text { Tensile } \\
\text { Strength }\end{array}$ & Rupture Strain & $\begin{array}{l}\text { Tensile } \\
\text { Strength }\end{array}$ & Rupture Strain & $\begin{array}{l}\text { Tensile } \\
\text { Strength }\end{array}$ & Rupture Strain & $\begin{array}{l}\text { Tensile } \\
\text { Strength }\end{array}$ \\
\hline & - & $\mathrm{kN} / \mathrm{m}$ & - & $\mathrm{kN} / \mathrm{m}$ & - & $\mathrm{kN} / \mathrm{m}$ & - & $\mathrm{kN} / \mathrm{m}$ \\
\hline 1 & 0.0804 & 142.5 & 0.0859 & 182.2 & 0.0622 & 147.7 & 0.0694 & 171.0 \\
\hline 2 & 0.0670 & 128.7 & 0.0929 & 187.0 & 0.0689 & 156.2 & 0.0745 & 171.3 \\
\hline 3 & 0.0784 & 138.0 & 0.0868 & 187.1 & 0.0567 & 145.6 & 0.0723 & 177.2 \\
\hline mean & $0.0753 \pm 0.0042$ & $136.4 \pm 4$ & $0.0885 \pm 0.0022$ & $185 \pm 2$ & $0.0626 \pm 0.0035$ & $149.8 \pm 3$ & $0.0721 \pm 0.0015$ & $173.1 \pm 2$ \\
\hline
\end{tabular}


Table A2. Elongation at break and tensile strength-wet $S$ type fabric.

\begin{tabular}{|c|c|c|c|c|c|c|c|c|}
\hline \multirow{3}{*}{$\begin{array}{l}\text { Specimens } \\
\text { No. }\end{array}$} & \multicolumn{2}{|c|}{$\begin{array}{c}\text { Weft-Flat Grips } \\
\text { SWp_Wet }\end{array}$} & \multicolumn{2}{|c|}{$\begin{array}{c}\text { Weft-Curved Grips } \\
\text { SW_Wet }\end{array}$} & \multicolumn{2}{|c|}{$\begin{array}{l}\text { Warp_Flat Grips } \\
\text { SOp_Wet }\end{array}$} & \multicolumn{2}{|c|}{$\begin{array}{c}\text { Warp-Curved Grips } \\
\text { SO_Wet }\end{array}$} \\
\hline & Rupture Strain & $\begin{array}{c}\text { Tensile } \\
\text { Strength }\end{array}$ & Rupture Strain & $\begin{array}{l}\text { Tensile } \\
\text { Strength }\end{array}$ & Rupture Strain & $\begin{array}{l}\text { Tensile } \\
\text { Strength }\end{array}$ & Rupture Strain & $\begin{array}{l}\text { Tensile } \\
\text { Strength }\end{array}$ \\
\hline & - & $\mathrm{kN} / \mathrm{m}$ & - & $\mathrm{kN} / \mathrm{m}$ & - & $\mathrm{kN} / \mathrm{m}$ & - & $\mathrm{kN} / \mathrm{m}$ \\
\hline 1 & 0.0738 & 112.4 & 0.0939 & 175.1 & 0.0508 & 129.6 & 0.0573 & 138.0 \\
\hline 2 & 0.0905 & 122.1 & 0.0776 & 180.3 & 0.0485 & 122.4 & 0.0625 & 151.1 \\
\hline 3 & 0.0989 & 120.8 & 0.1253 & 173.8 & 0.0448 & 134.1 & 0.0700 & 156.9 \\
\hline mean & $0.0878 \pm 0.0074$ & $118.5 \pm 3$ & $0.0989 \pm 0.0140$ & $176.4 \pm 2$ & $0.0480 \pm 0.0018$ & $128.7 \pm 3$ & $0.0633 \pm 0.0037$ & $148.6 \pm 6$ \\
\hline
\end{tabular}

Table A3. Elongation at break and tensile strength—air-dried S type fabric.

\begin{tabular}{|c|c|c|c|c|c|c|c|c|}
\hline \multirow{3}{*}{$\begin{array}{l}\text { Specimens } \\
\text { No. }\end{array}$} & \multicolumn{2}{|c|}{$\begin{array}{l}\text { Weft-Flat Grips } \\
\text { SWp_Air-Dried }\end{array}$} & \multicolumn{2}{|c|}{$\begin{array}{l}\text { Weft-Curved Grips } \\
\text { SW_Air-Dried }\end{array}$} & \multicolumn{2}{|c|}{$\begin{array}{l}\text { Warp_Flat Grips } \\
\text { SOp_Air-Dried }\end{array}$} & \multicolumn{2}{|c|}{$\begin{array}{l}\text { Warp-Curved Grips } \\
\text { SO_Air-Dried }\end{array}$} \\
\hline & Rupture Strain & $\begin{array}{l}\text { Tensile } \\
\text { Strength }\end{array}$ & Rupture Strain & $\begin{array}{l}\text { Tensile } \\
\text { Strength }\end{array}$ & Rupture Strain & $\begin{array}{l}\text { Tensile } \\
\text { Strength }\end{array}$ & Rupture Strain & $\begin{array}{c}\text { Tensile } \\
\text { Strength }\end{array}$ \\
\hline & - & $\mathrm{kN} / \mathrm{m}$ & - & $\mathrm{kN} / \mathrm{m}$ & - & $\mathrm{kN} / \mathrm{m}$ & - & $\mathrm{kN} / \mathrm{m}$ \\
\hline 1 & 0.0896 & 149.4 & 0.0800 & 177.0 & 0.0659 & 169.8 & 0.0705 & 166.1 \\
\hline 2 & 0.0718 & 134.7 & 0.1290 & 202.5 & 0.0619 & 150.8 & 0.0651 & 158.5 \\
\hline 3 & 0.0782 & 143.7 & 0.0835 & 173.5 & 0.0584 & 163.6 & 0.0913 & 172.4 \\
\hline mean & $0.0799 \pm 0.0052$ & $142.6 \pm 4$ & $0.0975 \pm 0.0158$ & $184.3 \pm 9$ & $0.0480 \pm 0.0018$ & $161.4 \pm 6$ & $0.0757 \pm 0.0079$ & $165.7 \pm 4$ \\
\hline
\end{tabular}

Table A4. Elongation at break and tensile strength—base specimens B type fabric.

\begin{tabular}{|c|c|c|c|c|c|c|c|c|}
\hline \multirow{3}{*}{$\begin{array}{l}\text { Specimens } \\
\text { No. }\end{array}$} & \multicolumn{2}{|c|}{$\begin{array}{c}\text { Weft-Flat Grips } \\
\text { BWp }\end{array}$} & \multicolumn{2}{|c|}{$\begin{array}{c}\text { Weft-Curved Grips } \\
\text { BW }\end{array}$} & \multicolumn{2}{|c|}{$\begin{array}{c}\text { Warp_Flat Grips } \\
\text { BOp }\end{array}$} & \multicolumn{2}{|c|}{$\begin{array}{c}\text { Warp-Curved Grips } \\
\text { BO }\end{array}$} \\
\hline & Rupture Strain & $\begin{array}{l}\text { Tensile } \\
\text { Strength }\end{array}$ & Rupture Strain & $\begin{array}{l}\text { Tensile } \\
\text { Strength }\end{array}$ & Rupture Strain & $\begin{array}{l}\text { Tensile } \\
\text { Strength }\end{array}$ & Rupture Strain & $\begin{array}{l}\text { Tensile } \\
\text { Strength }\end{array}$ \\
\hline & - & $\mathrm{kN} / \mathrm{m}$ & - & $\mathrm{kN} / \mathrm{m}$ & - & $\mathrm{kN} / \mathrm{m}$ & - & $\mathrm{kN} / \mathrm{m}$ \\
\hline 1 & 0.1736 & 101.8 & 0.1761 & 126.3 & 0.0436 & 189.0 & 0.0592 & 184.1 \\
\hline 2 & 0.1684 & 111.0 & 0.1755 & 123.4 & 0.0432 & 192.4 & 0.0401 & 179.7 \\
\hline 3 & 0.1606 & 101.4 & 0.1768 & 125.6 & 0.0387 & 192.5 & 0.0512 & 181.7 \\
\hline mean & $0.1675 \pm 0.0038$ & $104.7 \pm 3$ & $0.1761 \pm 0.0007$ & $125.1 \pm 1$ & $0.0418 \pm 0.0016$ & $191.3 \pm 1$ & $0.0502 \pm 0.0055$ & $181.9 \pm 1$ \\
\hline
\end{tabular}

Table A5. Elongation at break and tensile strength—wet B-type fabric.

\begin{tabular}{|c|c|c|c|c|c|c|c|c|}
\hline \multirow{3}{*}{$\begin{array}{c}\text { Specimens } \\
\text { No. }\end{array}$} & \multicolumn{2}{|c|}{$\begin{array}{c}\text { Weft-Flat Grips } \\
\text { BWp_Wet }\end{array}$} & \multicolumn{2}{|c|}{$\begin{array}{c}\text { Weft-Curved Grips } \\
\text { BW_Wet }\end{array}$} & \multicolumn{2}{|c|}{$\begin{array}{c}\text { Warp-Flat Grips } \\
\text { BOp_Wet }\end{array}$} & \multicolumn{2}{|c|}{$\begin{array}{c}\text { Warp-Curved Grips } \\
\text { BO_Wet }\end{array}$} \\
\hline & Rupture Strain & $\begin{array}{l}\text { Tensile } \\
\text { Strength }\end{array}$ & Rupture Strain & $\begin{array}{l}\text { Tensile } \\
\text { Strength }\end{array}$ & Rupture Strain & $\begin{array}{l}\text { Tensile } \\
\text { Strength }\end{array}$ & Rupture Strain & $\begin{array}{l}\text { Tensile } \\
\text { Strength }\end{array}$ \\
\hline & - & $\mathrm{kN} / \mathrm{m}$ & - & $\mathrm{kN} / \mathrm{m}$ & - & $\mathrm{kN} / \mathrm{m}$ & - & $\mathrm{kN} / \mathrm{m}$ \\
\hline 1 & 0.1673 & 107.8 & 0.1731 & 108.7 & 0.0428 & 174.7 & 0.0759 & 159.0 \\
\hline 2 & 0.2261 & 104.6 & 0.1860 & 106.1 & 0.0388 & 168.3 & 0.0357 & 158.0 \\
\hline 3 & 0.1570 & 101.2 & 0.1655 & 101.9 & 0.0403 & 172.3 & 0.0417 & 162.8 \\
\hline mean & $0.1835 \pm 0.0215$ & $104.5 \pm 2$ & $0.1749 \pm 0.0104$ & $105.5 \pm 3$ & $0.0407 \pm 0.0011$ & $171.8 \pm 2$ & $0.0511 \pm 0.0125$ & $159.9 \pm 1$ \\
\hline
\end{tabular}

Table A6. Elongation at break and tensile strength—air-dried B type fabric.

\begin{tabular}{|c|c|c|c|c|c|c|c|c|}
\hline \multirow{3}{*}{$\begin{array}{c}\text { Specimens } \\
\text { No. }\end{array}$} & \multicolumn{2}{|c|}{$\begin{array}{l}\text { Weft-Flat Grips } \\
\text { BWp_Air-Dried }\end{array}$} & \multicolumn{2}{|c|}{$\begin{array}{c}\text { Weft-Curved Grips } \\
\text { BW_Air-Dried }\end{array}$} & \multicolumn{2}{|c|}{$\begin{array}{l}\text { Warp_Flat Grips } \\
\text { BOp_Air-Dried }\end{array}$} & \multicolumn{2}{|c|}{$\begin{array}{c}\text { Warp-Curved Grips } \\
\text { BO_Air-Dried }\end{array}$} \\
\hline & Rupture Strain & $\begin{array}{l}\text { Tensile } \\
\text { Strength }\end{array}$ & Rupture Strain & $\begin{array}{l}\text { Tensile } \\
\text { Strength }\end{array}$ & Rupture Strain & $\begin{array}{l}\text { Tensile } \\
\text { Strength }\end{array}$ & Rupture Strain & $\begin{array}{l}\text { Tensile } \\
\text { Strength }\end{array}$ \\
\hline & - & $\mathrm{kN} / \mathrm{m}$ & - & $\mathrm{kN} / \mathrm{m}$ & - & $\mathrm{kN} / \mathrm{m}$ & - & $\mathrm{kN} / \mathrm{m}$ \\
\hline 1 & 0.1702 & 111.9 & 0.1834 & 133.4 & 0.0430 & 183.2 & 0.0477 & 174.7 \\
\hline 2 & 0.1736 & 108.1 & 0.1834 & 128.5 & 0.0485 & 185.8 & 0.0429 & 176.0 \\
\hline 3 & 0.1745 & 112.0 & 0.1780 & 130.3 & 0.0397 & 187.4 & 0.0463 & 173.6 \\
\hline mean & $0.1728 \pm 0.0013$ & $110.7 \pm 1$ & $0.1816 \pm 0.0018$ & $130.7 \pm 1$ & $0.0437 \pm 0.0026$ & $185.5 \pm 1$ & $0.0456 \pm 0.0014$ & $174.8 \pm 1$ \\
\hline
\end{tabular}


Table A7. Longitudinal stiffnesses of S type fabric.

\begin{tabular}{|c|c|c|c|c|c|c|}
\hline & \multicolumn{2}{|c|}{$\mathrm{S}$} & \multicolumn{2}{|c|}{ S_Wet } & \multicolumn{2}{|c|}{ S_Air-Dried } \\
\hline & Weft & Warp & Weft & Warp & Weft & Warp \\
\hline & $\underset{(-)}{(\mathbf{k N} / \mathrm{m})}$ & $\begin{array}{c}(\mathbf{k N} / \mathrm{m}) \\
(-)\end{array}$ & $\underset{(-)}{(\mathbf{k N} / \mathrm{m})}$ & $\begin{array}{c}(\mathbf{k N} / \mathrm{m}) \\
(-)\end{array}$ & $\begin{array}{c}(\mathrm{kN} / \mathrm{m}) \\
(-)\end{array}$ & $\begin{array}{c}(\mathrm{kN} / \mathrm{m}) \\
(-)\end{array}$ \\
\hline$F_{\mathrm{A}}$ & $187 \pm 5$ & $390 \pm 12$ & $191 \pm 5$ & $354 \pm 12$ & $179 \pm 5$ & $357 \pm 4$ \\
\hline$\varepsilon_{\mathrm{P} 1}$ & $0.059 \pm 0.002$ & $0.035 \pm 0.001$ & $0.056 \pm 0.002$ & $0.035 \pm 0.002$ & $0.059 \pm 0.002$ & $0.037 \pm 0.001$ \\
\hline$F_{\mathrm{B}}$ & $6168 \pm 63$ & $4842 \pm 137$ & $6294 \pm 102$ & $4603 \pm 92$ & $6454 \pm 101$ & $5064 \pm 60$ \\
\hline
\end{tabular}

Table A8. Longitudinal stiffnesses of B type fabric.

\begin{tabular}{|c|c|c|c|c|c|c|}
\hline & \multicolumn{2}{|c|}{ B } & \multicolumn{2}{|c|}{ B_Wet } & \multicolumn{2}{|c|}{ B_Air-Dried } \\
\hline & Weft & Warp & Weft & Warp & Weft & Warp \\
\hline & $\begin{array}{c}(\mathrm{kN} / \mathrm{m}) \\
(-)\end{array}$ & $\begin{array}{c}(\mathrm{kN} / \mathrm{m}) \\
(-)\end{array}$ & $\begin{array}{c}(\mathrm{kN} / \mathrm{m}) \\
(-)\end{array}$ & $\begin{array}{c}(\mathrm{kN} / \mathrm{m}) \\
(-)\end{array}$ & $\begin{array}{c}(\mathrm{kN} / \mathrm{m}) \\
(-)\end{array}$ & $\begin{array}{c}(\mathrm{kN} / \mathrm{m}) \\
(-)\end{array}$ \\
\hline$F_{\mathrm{A}}$ & $196 \pm 8$ & $913 \pm 135$ & $172 \pm 10$ & $1004 \pm 41$ & $165 \pm 6$ & $1079 \pm 72$ \\
\hline$\varepsilon_{\mathrm{P} 1}$ & $0.009 \pm 0.0003$ & $0.019 \pm 0.002$ & $0.01 \pm 0.001$ & $0.016 \pm 0.0005$ & $0.010 \pm 0.002$ & $0.018 \pm 0.001$ \\
\hline$F_{\mathrm{B}}$ & $\begin{array}{c}47 \pm 1 \\
0.144+0.002\end{array}$ & $6014 \pm 180$ & $\begin{array}{c}46 \pm 2 \\
0.149 \pm 0.003\end{array}$ & $6060 \pm 173$ & $\begin{array}{c}46 \pm 1 \\
0.153+0.002\end{array}$ & $5986 \pm 209$ \\
\hline $\begin{array}{l}\varepsilon_{\mathrm{P} 2} \\
F_{\mathrm{C}}\end{array}$ & $4459 \pm 88$ & - & $4338 \pm 64$ & - & $4441 \pm 71$ & - \\
\hline
\end{tabular}

\section{References}

1. Stimpfle, B. Recent developments in architectural fabric structures: Shopping mall Titan Plaza, Bogotá, Columbia. In Fabric Structures in Architecture; Llorens, J., Ed.; Woodhead Publishing: Sawston, UK, 2015; pp. 727-747.

2. Birchall, M. Recent developments in architectural fabric structures in Europe: The design and construction of the London 2012 Olympic Stadium and its context in the European fabric structures market. In Fabric Structures in Architecture; Llorens, J., Ed.; Woodhead Publishing: Sawston, UK, 2015; pp. 773-817.

3. Lombardi, S.; Monticelli, C. Recent developments in architectural fabric structures in Europe: The example of Winter Garden, Verona, Italy. In Fabric Structures in Architecture; Llorens, J., Ed.; Woodhead Publishing: Sawston, UK, 2015 ; pp. 749-771.

4. Ambroziak, A.; Kłosowski, P. Review of constitutive models for technical woven fabrics in finite element analysis. AATCC Rev. 2011, 5-6, 58-67.

5. Haas, R. The Stretching of the Fabric and the Shape of the Envelope. Natl. Advis. Comm. Aeronaut. Rep. 1918, 16, 155-250.

6. Peirce, F.T. The geometry of cloth structure. J. Text. Inst. Trans. 1937, 28, T45-T96. [CrossRef]

7. Argyris, J.; St. Doltsinis, I.; da silva, V.D. Constitutive modelling and computation of non-linear viscoelastic solids. Part I: Rheological models and numerical integration techniques. Comput. Methods Appl. Mech. Eng. 1991, 88, 135-163. [CrossRef]

8. Szostkiewicz-Chatain, C.; Hamelin, P. Numerical and experimental stiffness characterisations applied to soft textile composites for tensile structures. Mater. Struct. 1998, 31, 118-125. [CrossRef]

9. Bridgens, B.N.; Gosling, P.D. Direct stress-strain representation for coated woven fabrics. Comput. Struct. 2004, 82, 1913-1927. [CrossRef]

10. Pargana, J.B.; Lloyd-Smith, D.; Izzuddin, B.A. Advanced material model for coated fabrics used in tensioned fabric structures. Eng. Struct. 2007, 29, 1323-1336. [CrossRef]

11. Galliot, C.; Luchsinger, R.H. The shear ramp: A new test method for the investigation of coated fabric shear behaviour- Part II: Experimental validation. Compos. Part A Appl. Sci. Manuf. 2010, 41, 1750-1759. [CrossRef]

12. Derewonko, A.; Baranowski, P.; Rudnik, D. Simulation of Rubber-Coated Fabric Material Damage. Key Eng. Mater. 2011, 488-489, 585-588. [CrossRef]

13. Meng, L.; Wu, M. Study on stress relaxation of membrane structures in the prestress state by considering viscoelastic properties of coated fabrics. Thin-Walled Struct. 2016, 106, 18-27. [CrossRef]

14. Jekel, C.F.; Venter, G.; Venter, M.P. Obtaining a hyperelastic non-linear orthotropic material model via inverse bubble inflation analysis. Struct. Multidiscip. Optim. 2016, 54, 927-935. [CrossRef]

15. Hegyi, D.; Halász, M.; Molnár, K.; Szebenyi, G.; Sipos, A.A. An elastic phenomenological material law for textile composites and it's fitting to experimental data. J. Reinf. Plast. Compos. 2017, 36, 1343-1354. [CrossRef]

16. Jekel, C.F.; Venter, G.; Venter, M.P. Modeling PVC-coated polyester as a hypoelastic non-linear orthotropic material. Compos. Struct. 2017, 161, 51-64. [CrossRef]

17. Dib, W.; Bles, G.; Blaise, A.; Tourabi, A. Modelling of cyclic visco-elasto-plastic behaviour of coated woven fabrics under biaxial loading and finite strain. Int. J. Solids Struct. 2018, 154, 147-167. [CrossRef]

18. Motevalli, M.; Uhlemann, J.; Stranghöner, N.; Balzani, D. Geometrically nonlinear simulation of textile membrane structures based on orthotropic hyperelastic energy functions. Compos. Struct. 2019, 223, 110908. [CrossRef]

19. Xu, J.; Zhang, Y.; Wu, M.; Zhao, Y. A phenomenological material model for PTFE coated fabrics. Constr. Build. Mater. 2020, 237, 117667. [CrossRef] 
20. Zhao, B.; Hu, J.; Chen, W.; Chen, J.; Jing, Z. A nonlinear uniaxial stress-strain constitutive model for viscoelastic membrane materials. Polym. Test. 2020, 90, 106633. [CrossRef]

21. Reinhardt, H.W. On the biaxial testing and strength of coated fabrics. Exp. Mech. 1976, 16, 71-74. [CrossRef]

22. Day, A.S. Stress strain equations for non-linear behaviour of coated woven fabrics. In Proceedings of the IASS Symposium: Shells, Membranes and Space Frames; Elsevier: Osaka, Japan, 1986; pp. 17-24.

23. Chen, S.; Ding, X.; Fangueiro, R.; Yi, H.; Ni, J. Tensile behavior of PVC-coated woven membrane materials under uni- and bi-axial loads. J. Appl. Polym. Sci. 2008, 107, 2038-2044. [CrossRef]

24. Zouari, R.; Amar, S.B.; Dogui, A. Experimental and numerical analyses of fabric off-axes tensile test. J. Text. Inst. 2010, 101, 58-68. [CrossRef]

25. El-Messiry, M.; Youssef, S. Analysis of stress-strain of architect woven fabric strength under biaxial extensions. Alexandria Eng. J. 2011, 50, 297-303. [CrossRef]

26. Derewońko, A.; Niezgoda, T.; Bogusz, P. Uniaxial Tests of Limp Elastic Multi-Layer Materials. In Proceedings of the 9th International Conference On Composite Science And Technology: 2020-Scientific And Industrial Challenges, Naples, Italy, 24-26 April 2013; Meo, M., Ed.; University of Bath: Naples, Italy, 2013; pp. 745-754. ISBN 9781605951133.

27. Ambroziak, A.; Kłosowski, P. Mechanical properties for preliminary design of structures made from PVC coated fabric. Constr. Build. Mater. 2014, 50, 74-81. [CrossRef]

28. Chen, J.; Chen, W.; Zhang, D. Experimental study on uniaxial and biaxial tensile properties of coated fabric for airship envelopes J. Reinf. Plast. Compos. 2014, 33, 630-647. [CrossRef]

29. Chen, Y.; Chen, W. Deformation evaluation due to poisson's ratio variation of coated fabric for airship envelope. Res. J. Appl. Sci. Eng. Technol. 2014, 7, 1101-1107. [CrossRef]

30. Bögner-Balz, H.; Blum, R.; Köhnlein, J. Structural behaviour of fabrics and coatings for architectural fabric structures. In Fabric Structures in Architecture; Woodhead Publishing: Sawston, UK, 2015; pp. 123-157.

31. Ambroziak, A. Mechanical properties of Precontraint 1202S coated fabric under biaxial tensile test with different load ratios. Constr. Build. Mater. 2015, 80, 210-224. [CrossRef]

32. Ambroziak, A. Mechanical Properties of Polyester Coated Fabric Subjected to Biaxial Loading. J. Mater. Civ. Eng. 2015, 27, 04015012. [CrossRef]

33. Chen, J.; Chen, W. Central Crack Tearing Testing of Laminated Fabric Uretek3216LV under Uniaxial and Biaxial Static Tensile Loads. J. Mater. Civ. Eng. 2016, 28, 04016028. [CrossRef]

34. Wu, M.; Li, Y.; Shang, Y. Statistical Characteristics of Ethylene Tetrafluoroethylene Foil's Mechanical Properties and Its Partial Safety Factors. J. Mater. Civ. Eng. 2016, 28, 04016004. [CrossRef]

35. Shi, T.; Chen, W.; Gao, C.; Hu, J.; Zhao, B.; Zhang, D.; Qiu, Z. Shear behavior of architectural coated fabrics under biaxial bias-extension. Constr. Build. Mater. 2018, 187, 964-973. [CrossRef]

36. Chen, J.; Zhou, H.; Chen, W.; Wang, M.; Zhao, B.; Sun, W. Full-strain range characteristics of the Poisson's ratio for coated biaxial warp-knitted fabrics under bias tensile loading. Text. Res. J. 2019, 89, 1997-2009. [CrossRef]

37. Shi, T.; Hu, J.; Chen, W.; Gao, C. Biaxial tensile behavior and strength of architectural fabric membranes. Polym. Test. 2020, 82, 106230. [CrossRef]

38. Chen, J.; Luo, F.; Fan, J.; Chen, W.; Wang, M.; Xia, Y. Detailed Deformation Behaviors and Tensile Parameters for Coated Warp-Knitted Fabrics in 2D Stress Space. J. Mater. Civ. Eng. 2021, 33, 04021333. [CrossRef]

39. Gao, C.; Chen, W.; Hu, J.; Zhao, B. A new constitutive model on biaxial tensile behavior of architectural fabrics. Polym. Test. 2020, 87, 106519. [CrossRef]

40. Ansell, M.P.; Hill, C.A.S.; Allgood, C. Architectural PTFE-Coated Glass Fabrics-Their Structure and Limitations. Text. Res. J. 1983, 53, 692-700. [CrossRef]

41. Ambroziak, A.; Kłosowski, P. Mechanical properties of polyvinyl chloride-coated fabric under cyclic tests. J. Reinf. Plast. Compos. 2014, 33, 225-234. [CrossRef]

42. Yingying, Z.; Qilin, Z.; Ke, L.; Bei-lei, K. Experimental analysis of tensile behaviors of polytetrafluoroethylene-coated fabrics subjected to monotonous and cyclic loading. Text. Res. J. 2014, 84, 231-245. [CrossRef]

43. Wang, F.; Chen, Y.; Xu, W.; Song, Z.; Fu, G. Experimental study on uniaxial tensile and welding performance of a new coated fabric for airship envelopes. J. Ind. Text. 2017, 46, 1474-1497. [CrossRef]

44. Xu, J.; Zhang, Y.; Xue, J. Off-axial failure analysis of polytetrafluoroethylene-coated woven glass fibers under different loading rates. J. Ind. Text. 2017, 47, 310-330. [CrossRef]

45. Żerdzicki, K.; Kłosowski, P.; Woznica, K. Analysis of the cyclic load-unload-reload tests of VALMEX aged fabric. In Shell Structures: Theory and Applications; Pietraszkiewicz, W., Witkowski, W., Eds.; CRC Press: London, UK, 2018; Volume 4, pp. 477-480.

46. Zhao, B.; Hu, J.; Chen, W.; Chen, J.; Jing, Z. Simultaneous uniaxial creep testing of time-dependent membrane materials with optical devices. Mater. Today Commun. 2019, 21, 100655. [CrossRef]

47. Uhlemann, J.; Surholt, F.; Westerhoff, A.; Stranghöner, N.; Motevalli, M.; Balzani, D. Saturation of the stress-strain behaviour of architectural fabrics. Mater. Des. 2020, 191, 108584. [CrossRef]

48. Eun, J.H.; Kim, M.S.; Sung, S.M.; Choi, B.K.; Jang, I.U.; Kim, D.; Lee, J.S. Effect of the viscosity of polyvinyl chloride resin and weaving structures of polyester fabric on the off-axis mechanical properties of PVC coated fabric. J. Ind. Text. 2020, 152808372098017. [CrossRef] 
49. Chen, J.; Chen, W.; Zhou, H.; Zhao, B.; Ding, Y.; Zhang, N. Central tearing characteristics of laminated fabrics: Effect of slit parameter, off-axis angle, and loading speed. J. Reinf. Plast. Compos. 2017, 36, 921-941. [CrossRef]

50. Eltahan, E. Structural parameters affecting tear strength of the fabrics tents. Alexandria Eng. J. 2018, 57, 97-105. [CrossRef]

51. Chen, J.; Chen, W.; Zhou, H.; Zhao, B.; Wang, M.; Sun, W.; He, S. Fracture failure analysis and bias tearing strength criterion for a laminated fabric. J. Ind. Text. 2018, 47, 1496-1527. [CrossRef]

52. Sun, X.; He, R.; Wu, Y. A novel tearing residual strength model for architectural coated fabrics with central crack. Constr. Build. Mater. 2020, 263, 120133. [CrossRef]

53. He, R.; Sun, X.; Wu, Y.; Tang, G.; Carvelli, V. Biaxial tearing properties of woven coated fabrics using digital image correlation. Compos. Struct. 2021, 272, 114206. [CrossRef]

54. Sun, X.; He, R.; Wu, Y.; Wang, T. Uniaxial tearing properties and the tearing residual strength models of PTFE coated fabric. Structures 2021, 33, 1354-1364. [CrossRef]

55. Xu, J.; Zhang, Y.; Song, J.; Zhao, Y.; Zhang, L. Quasi-static puncture resistance behaviors of architectural coated fabric. Compos. Struct. 2021, 114307. [CrossRef]

56. Li, X.; Zhang, Y.; Xu, J.; Zhang, L.; Wu, M.; Zhao, Q. Central tearing behavior of PVDF coated fabrics with multiple initial notches. Polym. Compos. 2021, 42, 1049-1058. [CrossRef]

57. Chen, Y.; Lloyd, D.W.; Harlock, S.C. Mechanical Characteristics of Coated Fabrics. J. Text. Inst. 1995, 86, 690-700. [CrossRef]

58. Wang, P.; Zhang, Y. The Tensile Strength of Neat and Coated Woven Fabrics. Key Eng. Mater. 2011, 480-481, 448-452. [CrossRef]

59. Wang, P.; Sun, B.; Gu, B. Comparison of stab behaviors of uncoated and coated woven fabrics from experimental and finite element analyses. Text. Res. J. 2012, 82, 1337-1354. [CrossRef]

60. Bassett, R.J.; Postle, R.; Pan, N. Experimental Methods for Measuring Fabric Mechanical Properties: A Review and Analysis. Text. Res. J. 1999, 69, 866-875. [CrossRef]

61. Klosowski, P.; Zagubien, A.; Woznica, K. Investigation on rheological properties of technical fabric Panama. Arch. Appl. Mech. 2004, 73, 661-681. [CrossRef]

62. Kłosowski, P.; Komar, W.; Woźnica, K. Finite element description of nonlinear viscoelastic behaviour of technical fabric. Constr. Build. Mater. 2009, 23, 1133-1140. [CrossRef]

63. Żerdzicki, K.; Kłosowski, P.; Woźnica, K. Application of the Bodner-Partom constitutive equations for modelling the technical fabric Valmex used for the hanging roof of the Forest Opera in Sopot. In Proceedings of the Shell structures: Theory and Applications; Pietraszkiewicz, W., Gorski, J., Eds.; Taylor \& Francis/Balkema: London, UK, 2014; pp. 579-582.

64. Uhlemann, J.; Stranghöner, N.; Saxe, K. Stiffness parameters for architectural fabrics: An analysis of two determination procedures. Struct. Eng. Int. J. Int. Assoc. Bridg. Struct. Eng. 2015, 25, 9-19. [CrossRef]

65. Chen, W.; Hao, H.; Irawan, P.; Chen, S.; Meng, Q. Experimental investigations of fabric material against projectile impacts. Constr. Build. Mater. 2016, 104, 142-153. [CrossRef]

66. Van Craenenbroeck, M.; Puystiens, S.; De Laet, L.; Van Hemelrijck, D.; Van Paepegem, W.; Mollaert, M. Integrated analysis of kinematic form active structures for architectural applications: Experimental verification. Eng. Struct. 2016, 123, 59-70. [CrossRef]

67. Meng, J.; Lv, M.; Tan, D.; Li, P. Mechanical properties of woven fabric composite for stratospheric airship envelope based on stochastic simulation. J. Reinf. Plast. Compos. 2016, 35, 1434-1443. [CrossRef]

68. Meng, J.; Lv, M.; Qu, Z.; Li, P. Mechanical Properties and Strength Criteria of Fabric Membrane for the Stratospheric Airship Envelope. Appl. Compos. Mater. 2017, 24, 77-95. [CrossRef]

69. Zhao, B.; Chen, W.; Hu, J.; Chen, J.; Qiu, Z.; Zhou, J. In Situ Determination of Stress Distribution of Inflatable Membrane Structure Using Force Finding Method. J. Eng. Mech. 2017, 143, 04017042. [CrossRef]

70. Dinh, T.D.; Rezaei, A.; Linthout, T.; Mollaert, M.; Van Hemelrijck, D.; Van Paepegem, W. A computational compensation method for fabric panels of tensioned membrane structures using a shape optimization method based on gradientless algorithms. Int. J. Solids Struct. 2017, 112, 16-24. [CrossRef]

71. Klosowski, P.; Zerdzicki, K.; Woznica, K. Identification of Bodner-Partom model parameters for technical fabrics. Comput. Struct. 2017, 187, 114-121. [CrossRef]

72. Chen, J.; Chen, W.; Wang, M.; Ding, Y.; Zhou, H.; Zhao, B.; Fan, J. Mechanical Behaviors and Elastic Parameters of Laminated Fabric URETEK3216LV Subjected to Uniaxial and Biaxial Loading. Appl. Compos. Mater. 2017, 24, 1107-1136. [CrossRef]

73. Ambroziak, A.; Kłosowski, P. Polyester sail technical woven fabric behaviour under uniaxial and biaxial tensile tests. J. Theor. Appl. Mech. 2018, 56, 227-238. [CrossRef]

74. Xu, J.; Zhang, Y.; Wu, M.; Zhao, Y. Experimental analysis of off-axis mechanical behaviors of PVC coated fabrics subjected to cyclic loading. Polym. Test. 2019, 80, 106090. [CrossRef]

75. Chen, J.; Zhao, B.; Chen, W.; Wang, M.; Guan, X.; Wu, S. Response surface analysis of biaxial mechanical properties and elastic parameters for woven fabric composites. J. Ind. Text. 2019, 49, 219-242. [CrossRef]

76. Khaothong, K. Analysis of failing load and optimization of hot air welding parameters on PVC-acrylic coated polyester fabric by Taguchi and ANOVA technique. Eng. J. 2019, 23, 331-344. [CrossRef]

77. Yingying Zhang; Qilin Zhang; Chuanzhi Zhou; Ying Zhou Mechanical properties of PTFE coated fabrics. J. Reinf. Plast. Compos. 2010, 29, 3624-3630. [CrossRef]

78. Ambroziak, A.; Kosowski, P. Influence of thermal effects on mechanical properties of PVDF-coated fabric. J. Reinf. Plast. Compos. 2014, 33. [CrossRef] 
79. Jabbari, M.; Åkesson, D.; Skrifvars, M.; Taherzadeh, M.J. Novel lightweight and highly thermally insulative silica aerogel-doped poly(vinyl chloride)-coated fabric composite. J. Reinf. Plast. Compos. 2015, 34, 1581-1592. [CrossRef]

80. Zhang, Y.; Xu, S.; Zhang, Q.; Zhou, Y. Experimental and Theoretical Research on the Stress-Relaxation Behaviors of PTFE Coated Fabrics under Different Temperatures. Adv. Mater. Sci. Eng. 2015, 2015, 319473. [CrossRef]

81. Meng, J.; Cao, S.; Qu, Z.; Li, J.; Lv, M. Thermoelasticity of a Fabric Membrane Composite for the Stratospheric Airship Envelope Based on Multiscale Models. Appl. Compos. Mater. 2017, 24, 209-220. [CrossRef]

82. Yu, Y.; Cao, Z.; Sun, Y. Mechanical properties of four types of PVC-coated woven fabrics at high-temperature and after exposure to high-temperature. Structures 2021, 33, 830-840. [CrossRef]

83. Sun, G.; Li, L.; Xue, S.; Yang, Y.; Wu, M. Mechanical Properties of Polyester-Coated Fabric Membrane Material Subjected to Uniaxial Loading at Elevated Temperatures. J. Mater. Civ. Eng. 2021, 33, 04021169. [CrossRef]

84. Li, Y.; Liu, T.; Yang, B.; Zhang, Q.; Zhang, Y. Effects of natural ageing on mechanical properties of PVDF-coated fabrics. Struct. Eng. Int. 2016, 26, 348-356. [CrossRef]

85. Zhang, Y.; Zhang, M. Aging Properties of Polyvinylidenefluoride-Coated Polyesters Used in Tensioned Membrane Structure: Effect of Loading Protocol and Environment. Adv. Mater. Sci. Eng. 2017, 2017, 8789247. [CrossRef]

86. Zerdzicki, K.; Klosowski, P.; Woznica, K. Influence of service ageing on polyester-reinforced polyvinyl chloride-coated fabrics reported through mathematical material models. Text. Res. J. 2019, 89, 1472-1487. [CrossRef]

87. João, L.S.; Carvalho, R.; Fangueiro, R. A Study on the Durability Properties of Textile Membranes for Architectural Purposes. Procedia Eng. 2016, 155, 230-237. [CrossRef]

88. Yang, B.; Shang, Y.; Wu, M.; Yu, Z.; Qu, X. Statistical characteristics of naturally aged PVDF-coated fabrics' mechanical properties and structural reliability index. Polym. Test. 2019, 80, 106143. [CrossRef]

89. Klosowski, P.; Zerdzicki, K.; Woznica, K. Influence of artificial thermal ageing on polyester-reinforced and polyvinyl chloride coated AF9032 technical fabric. Text. Res. J. 2019, 89, 4632-4646. [CrossRef]

90. Dobilaitè, V.; Jucienè, M.; Bliūdžius, R.; Šveikauskaitè, L. Investigation of some weathering impacts on tearing properties of PVC-coated fabrics used for architectural purposes. J. Ind. Text. 2020, 152808372098238. [CrossRef]

91. Shang, Y.; Yang, B.; Wu, M.; Tao, Y.; Qin, J. Degradation of PVDF-Coated Fabrics after Engineering Applications: Correlations between Surface Microstructure, Physical Properties, and Mechanical Properties Based on Statistical Analysis. Adv. Polym. Technol. 2021, 2021, 9345451. [CrossRef]

92. Toyoda, H.; Sakabe, H.; Itoh, T.; Konishi, T. Degradation of Polytetrafluoroethylene-Coated Glass Fiber Fabrics by Hot Water Treatment. Sen'i Gakkaishi 1995, 51, 282-286. [CrossRef]

93. Razak, H.A.; Chua, C.S.; Toyoda, H. Weatherability of coated fabrics as roofing material in tropical environment. Build. Environ. 2004, 39, 87-92. [CrossRef]

94. Asadi, H.; Uhlemann, J.; Stranghoener, N.; Ulbricht, M. Water influence on the uniaxial tensile behavior of polytetrafluoroethylenecoated glass fiber fabric. Materials 2021, 14, 846. [CrossRef]

95. ISO (International Organization for Standardization). ISO 1421 Rubber or Plastics-Coated Fabrics-Determination of Tensile Strength and Elongation at Brake; International Organization for Standardization: Geneva, Switzerland, 2016.

96. Heiberger, R.M.; Neuwirth, E. One-Way ANOVA. In R Through Excel; Springer New York: New York, NY, USA, $2009 ;$ pp. 165-191.

97. Górecki, T.; Smaga, Ł. A comparison of tests for the one-way ANOVA problem for functional data. Comput. Stat. 2015, 30, 987-1010. [CrossRef]

98. Hanusz, Z.; Tarasinska, J.; Zieliński, W. Shapiro-Wilk Test with Known Mean. REVSTAT—Stat. J. 2016, 14, 89-100.

99. Gamage, J.; Weerahandi, S. Size performance of some tests in one-way ANOVA. Commun. Stat. Part B Simul. Comput. 1998, 27, 625-640. [CrossRef] 